\title{
Pygmy Rabbit Distribution in Beaverhead and Madison Counties
}

Prepared for

Bureau of Land Management

Montana State Office

Dillon Field Office

1005 Selway Drive

Dillon, Montana 59725-9431

Task Order \#23

Assistance Agreement \#ESA 010009

Prepared by:

Susan Lenard, Paul Hendricks, Coburn Currier, and Bryce A. Maxell

Montana Natural Heritage Program

Natural Resources Information System

Montana State Library

P.O. Box 201800

1515 East Sixth Avenue

Helena, Montana 59620-1800

June 2005

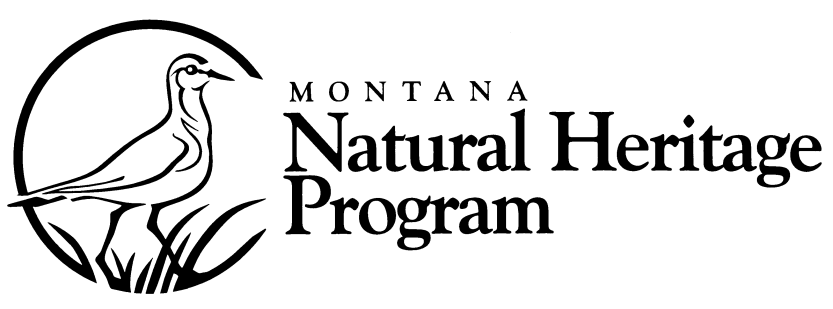





\section{Pygmy Rabbit Distribution in Beaverhead and Madison Counties}

Prepared for

Bureau of Land Management

Montana State Office

Dillon Field Office

1005 Selway Drive

Dillon, Montana 59725-9431

Task Order \#23

Assistance Agreement \#ESA 010009

Prepared by:

Susan Lenard, Paul Hendricks, Coburn Currier, and Bryce A. Maxell

Montana Natural Heritage Program

Natural Resource Information System

Montana State Library

June 2005
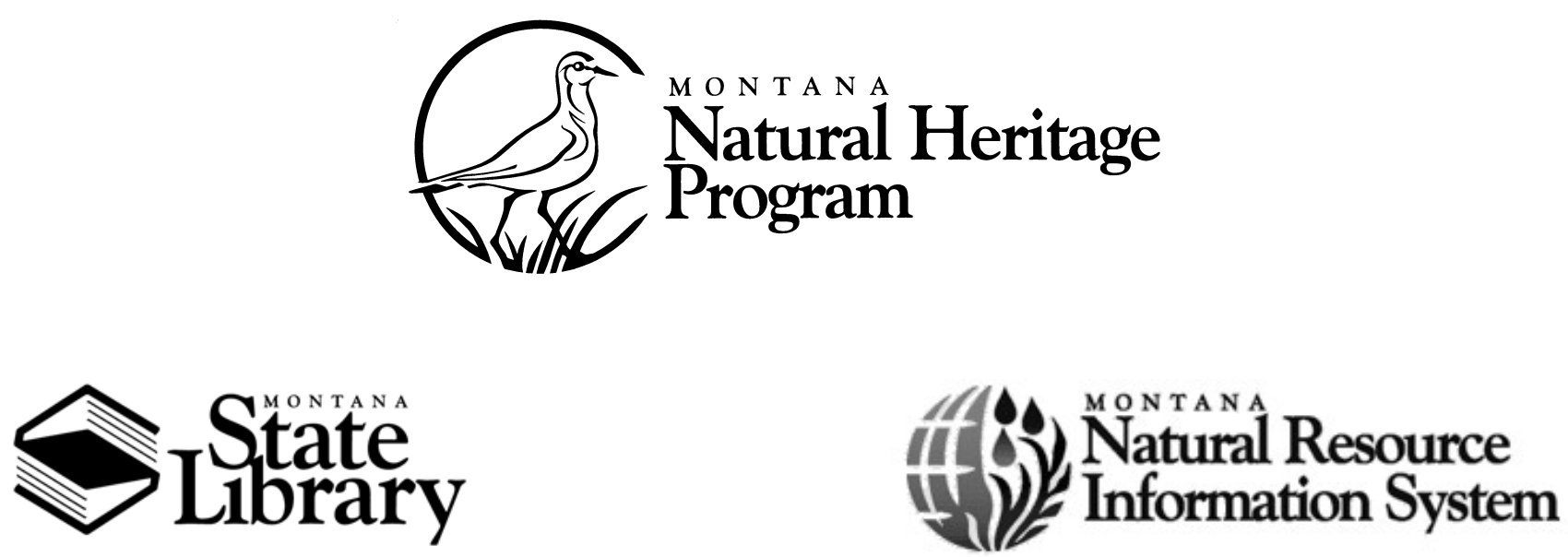

(C) Montana Natural Heritage Program

P.O. Box 201800, 1515 East Sixth Avenue, Helena, MT 59620-1800, (406) 444-3655 
This document should be cited as:

Lenard, S., P. Hendricks, C. Currier, and B. A. Maxell. 2005. Pygmy Rabbit Distribution in Beaverhead and Madison Counties. A report to the Bureau of Land Management, Dillon Field Office. Montana Natural Heritage Program, Helena, MT. 21 pp. plus appendices. 


\section{EXECUTIVE SUMMARY}

The pygmy rabbit (Brachylagus idahoensis) is a sage dependent species whose primary distribution is centered on four states at the core of the Great Basin (Nevada, Utah, Oregon, and Idaho). Four additional states (California, Wyoming, Washington, and Montana) currently support relatively small populations at the periphery of their range. This small mammal is recognized as a state Species of Concern in all of the states it occurs; with the isolated population in the state of Washington having the added distinction of being federally listed as endangered under the Endangered Species Act (Washington Dept. of Fish \& Wildlife 1993, USFWS 2003, NatureServe 2005).

The majority of information on pygmy rabbit localities in Montana prior to this study resulted from field survey work performed and/or summarized by Ryan Rauscher of the Montana Department of Fish, Wildlife, \& Parks and Chuck Bowey of the U.S. Forest Service Beaverhead-Deerlodge National Forest during 1996 and 1997, and Jim Roscoe of the Dillon Office of the BLM in subsequent years (MTNHP POD 2005).

The Montana Natural Heritage Program conducted field surveys in 2004 and 2005 for the Dillon field office of the Bureau of Land Management to assess current pygmy rabbit distribution in Montana. Field investigations focused on Beaverhead and Madison Counties in areas of known historic use and areas with apparent suitable habitat where no activity was previously recorded. Because the historic locations of Horse Prairie, Medicine Lodge Creek (south of Ayers Canyon), Badger Gulch/Sagebrush Creek, and Upper Ermont Creek were inaccessible due to deep to snow, they were ultimately not visited and should be a high priority for future surveys. Numerous observations confirmed continued activity in areas of historic use and new areas of activity were identified in both counties, expanding the documented distribution of the species in the state.

Recognition of the need for a more comprehensive assessment of pygmy rabbit distribution fueled an interest in the development of a predictive model to estimate areas of suitable pygmy rabbit habitat in Montana. We generated four different predictive models using elevation, slope, depth to bedrock, clay content, and vegetation covertype from known pygmy rabbit locations. Two separate levels of fit to data in the training dataset (conservative which fit up to approximately $70 \%$ of the values in the training dataset and liberal which fit up to approximately $90 \%$ of the values in the training dataset) and two vegetation covertype layers (the 30-meter resolution GAP Analysis covertype layer (Fisher et al. 1998) and the Southwest Montana Sagebrush Canopy Cover Classification (SILC3) (WSAL 2005) were investigated in the models. In general, conservative models explained up to 50 percent of the known pygmy rabbit locations, while liberal models explained up to 93 percent of the known points. However, both vegetation covertype schemes identified pygmy rabbit point locations in grassland cover types and generally did not identify sagebrush dominated areas as the cover types used by pygmy rabbits. Thus, both vegetation covertype schemes were poor predictors of sagebrush cover, and therefore ultimately did a poor job of predicting areas of known pygmy rabbit occupation.

The next steps in modeling pygmy rabbit distribution in Montana would be to improve the accuracy of vegetation covertype mapping and survey both areas of predicted presence without documented occurrence and areas with predicted absence. 


\section{ACKNOWLEDGEMENTS}

We thank Jim Roscoe of the Dillon Field Office of the Bureau of Land Management for his support and patience through all phases of this project. We are grateful for the opportunity to explore Beaverhead and Madison Counties in search of pygmy rabbits. Karen Walker accommodated our many requests and made an exceptional effort in the development of the models and associated maps for this project. Phil Johnson provided valuable suggestions in the writing of this report. 


\section{TABLE OF CONTENTS}

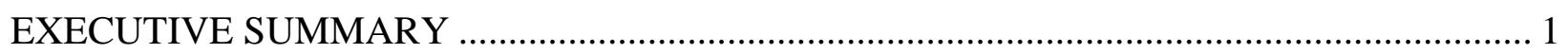

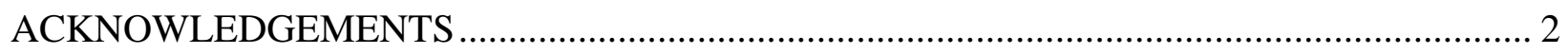

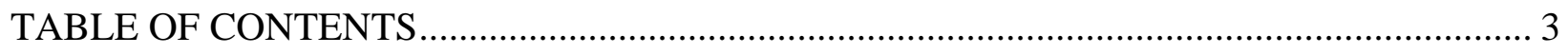

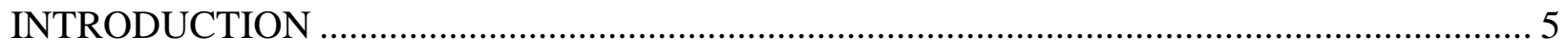

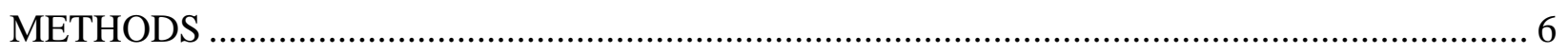

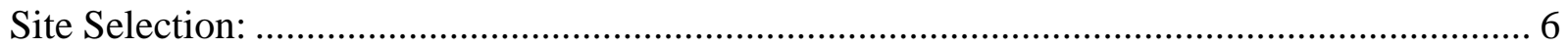

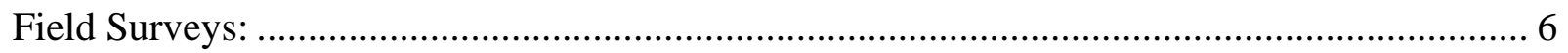

Sagebrush Site Characteristics:........................................................................................ 6

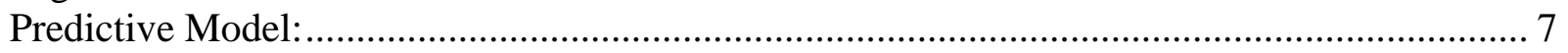

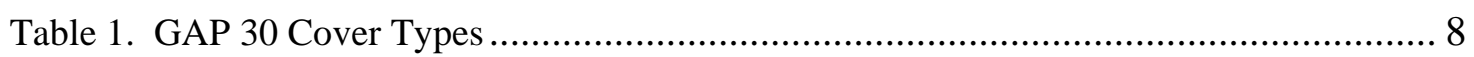

Table 2. Southwestern MT Sagebrush Canopy Cover Classification (SILC3).......................... 8

Table 3. Variables and Model Components for Pygmy Rabbit Distribution............................ 8

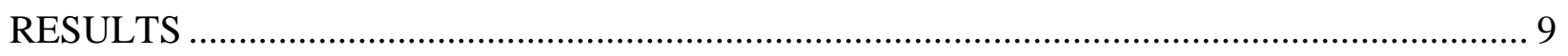

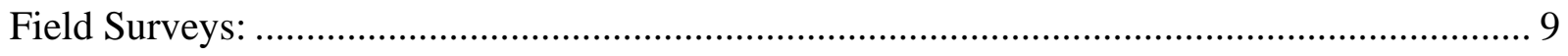

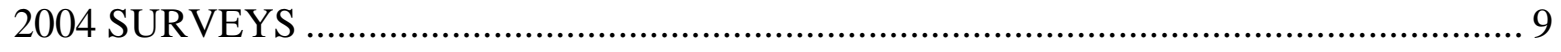

2004 Surveys of Historic Locations................................................................................ 9

2004 Surveys Of Areas Without Previously Recorded Activity ....................................... 10

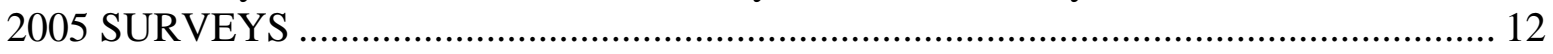

2005 Surveys of Locations for Possible Pygmy Rabbit Presence ……………………..... 12

Sagebrush Site Characteristics:................................................................................................. 16

Table 4. Results of Vegetation Measurements During 2005 Field Surveys ........................ 16

Table 5. Shrub species composition of sites by activity status ....................................... 17

Table 6. Mean height of shrub species by activity status ............................................ 17

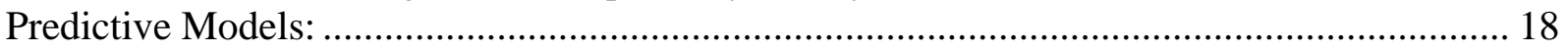

Table 7. Model Fit ................................................................................................. 18

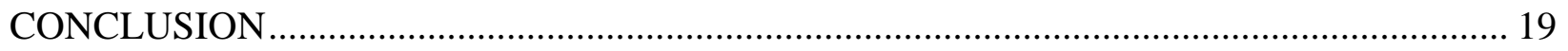

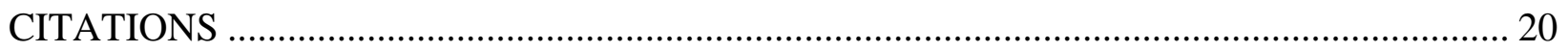

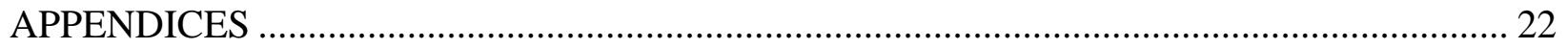

Appendix 1. Data Output for Model Development .................................................................. 24

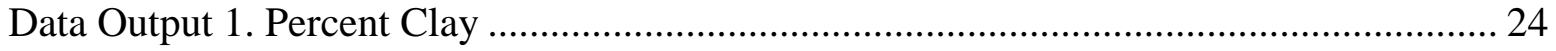

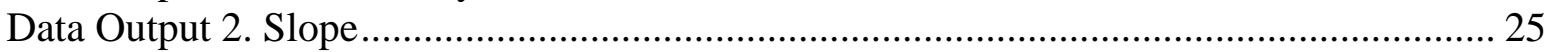

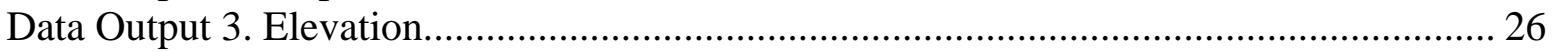

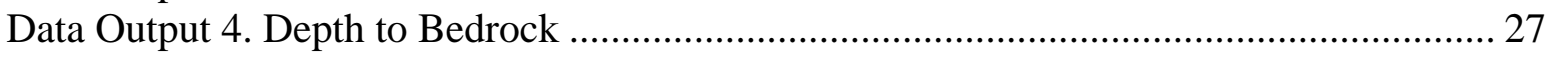

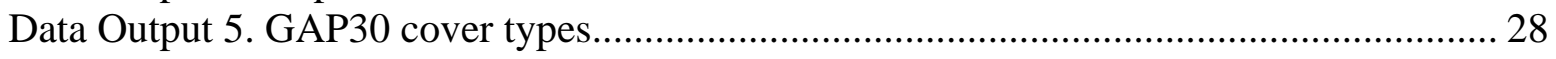

Data Output 6. SILC3 cover types .......................................................................................... 29 
Appendix 2: Photos ........................................................................................................ 30

Photo 1. Sweetwater Creek ..................................................................................... 30

Photo 2. Pellet Pile - Sweetwater Creek ………........................................................ 30

Photo 3. Example of pygmy rabbit burrow hole, note droppings at margins......................... 31

Photo 4. Pygmy rabbit at burrow entrance at Sweetwater Basin............................................. 31

Photo 5. Size comparison of pygmy rabbit droppings.......................................................... 32

Photo 6. Pygmy rabbit tracks, urine stain, and sagebrush floret clippings in snow.............. 32

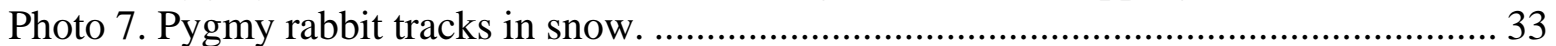

Photo 8. Pygmy rabbit burrow entrance in snow............................................................... 33

Photo 9. Absence of white tail clearly distinguishes pygmy rabbits from cottontail rabbits.34

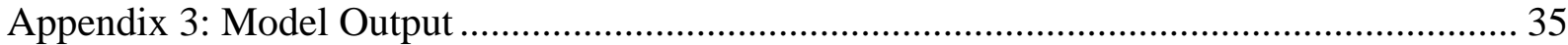

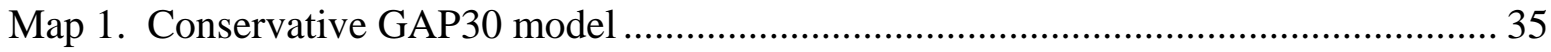

Map 2. Liberal GAP30 Model .......................................................................................... 36

Map 3. Conservative SILC3 Model ................................................................................... 37

Map 4. Liberal SILC3 model............................................................................................ 38

Map 5. Liberal model with SILC3 moderate and high sagebrush cover types...................... 39 


\section{INTRODUCTION}

The pygmy rabbit (Brachylagus idahoensis) is a species of numerous distinctions. Generally weighing less than a pound, they are one of the smallest leporids in the world and the most diminutive rabbit in North America (Roberts 2001). They are also the only rabbit on the continent to dig their own burrows and are endemic to sagebrush (Artemisia tridentata) habitat (Green \& Flinder 1980, Washington Dept. of Fish \& Wildlife 1995, Katzner \& Parker 1997, Simons \& Laundre 2004). Since pygmy rabbits have no known metabolic torpor, and are not known to cache food, they are entirely dependent upon a continuous food supply throughout the winter months (Katzner and Parker 1997). Dense stands of sagebrush provide a reliable food source, comprising 99 percent of their diet in the winter and 51 percent during the summer (Heady et al. 2001). In addition to dense sagebrush, deep alluvial soil is considered a key component of suitable habitat in order to allow the species to dig its burrows. Given the nature of these elements, the distribution of this sage endemic species is not continuous across its range (Roberts 2001, Heady et al. 2001).

Pygmy rabbits occupy portions of the big sagebrush dominated landscapes of the Great Basin states, with the center of their range occurring in northern Nevada, southeastern Oregon, southern Idaho, and northern Utah. Pygmy rabbit populations also extend on a limited basis into California, southern Utah, Wyoming, and southwestern Montana. A separate population of pygmy rabbits in the state of Washington was listed federally as endangered in 2003, and although threats to the long-term sustainability of this population are more pronounced because of its isolation, threats across the entire species range have raised concerns about the conservation of this unique sage-dependent lagomorph. Habitat destruction and fragmentation represent both historic and ongoing threats with sagebrush being the target of conversion to cropland, and facing threats from exotic plant species and overgrazing (Gabler et al. 2000, NatureServe 2005).
Because these threats are present throughout the species range, pygmy rabbits are estimated to be in decline (Weiss \& Verts 1984, Washington Department of Fish \& Wildlife 1995, Katzner \& Parker 1997). Federal listing of the species in Washington served to highlight the deficiency of information on status and distribution of the pygmy rabbit elsewhere in its range. In the state of Montana, the pygmy rabbit is currently identified as a state Species of Concern (G4/S3) by the Montana Natural Heritage Program and the Montana Department of Fish, Wildlife, and Parks and as a sensitive species by the Bureau of Land Management and the U.S. Forest Service (MTNHP 2004).

The only formal field surveys of pygmy rabbit distribution in Montana, since the first documented observation in the state in 1918, were conducted by Ryan Rauscher of the Montana Department of Fish, Wildlife, \& Parks in 1996 and 1997 (Weiss and Verts 1984, Rauscher 1997, Rachlow and Svancara 2003). Additional observations over the past decade by Chuck Bowey of the U.S. Forest Service and Jim Roscoe, Dillon Field Office of the Bureau of Land Management, supplemented this information. For our purposes, all documented pygmy rabbit locations prior to our study (in 2004 and 2005) were considered, and are referred to in this report, as "historic." In areas without previously documented occupation, we relied on BLM personnel to provide us with locations containing the general habitat characteristics of areas known to be used by pygmy rabbits throughout their range.

Given the inability of field personnel to survey all sagebrush habitat in southwestern Montana for the presence of pygmy rabbits, the development of a predictive model to identify areas as potentially suitable can guide future survey efforts and be a valuable tool in conservation planning. Eliminating areas as unsuitable for occupation is also important and can be particularly helpful when known occurrences of the species suggest a highly fragmented distribution, even at a relatively small scale (Rachlow and Svancara 2003). Recognizing the value of predictive modeling to 
future surveys and management decisions and the limitations of predictive models resulting from GIS coverages with low spatial resolution and/or accuracy, we developed a suite of 4 models: (1) Conservative Model with GAP covertypes; (2) Liberal Model with GAP covertypes; (3) Conservative Model with Southwest Montana Sagebrush Canopy Cover Classification (SILC3) covertypes; and (4) Liberal Model with SILC3 covertypes. In general, conservative models included categories of individual variables that encompassed approximately $70 \%$ of known pygmy rabbit locations while liberal models included categories of individual variables that encompassed approximately $90 \%$ of known pygmy rabbit locations.

\section{METHODS}

\section{Site Selection:}

Field surveys for pygmy rabbit activity were focused primarily in Beaverhead County in 2004 and Madison County in 2005. Locations of known historic use were derived from the Point Observation Database (POD) housed at the Montana Natural Heritage Program, and personal communication with Dillon-BLM personnel. For most historic areas surveyed, GPS point locations and/or site location descriptions were available to relocate burrows discovered during the 1996-97 survey effort.

Areas selected for survey in this project included locations in/or adjacent to Clark Canyon Reservoir, Lime Kiln Gulch, Grasshopper Creek, Sheep Corral Gulch, Bannack, Horse Prairie, Medicine Lodge Creek, Badger Gulch/Sagebrush Creek, Upper Ermont Creek, Sweetwater Basin, Nevada City-Herman Gulch, Ruby River Reservoir. In addition, new areas were surveyed where no previously documented use was recorded in order to gain a better understanding of the extent of pygmy rabbit distribution in Montana. These sites were somewhat subjectively selected, but contained a vegetative cover of big sagebrush (Artemisia tridentata) and other landscape features similar to those observed at other locations of known activity in this portion of the state.

\section{Field Surveys:}

Three members of the Montana Natural Heritage Program staff performed the field surveys in early February 2004 and late-January/earlyFebruary 2005. The methods employed involved scanning the general survey site for dense stands of sagebrush and then walking a serpentine route through these stands in order to cover the most ground in the shortest amount of time. The overall search involved walking a circular-looped path through an area to maximize the amount of ground surveyed without covering the same ground twice. While surveying, we generally walked back and forth across the principal route by as much as 20 to 30 meters. Often, taller, denser sagebrush clumps were specifically targeted for survey, or tracks or scat were followed in order to locate burrows. Using these methods, our survey routes were not random, straight, or well defined, but followed general protocols recommended for pygmy rabbit surveys (Roberts 2001, Ulmschneider 2003).

Pygmy rabbit presence was confirmed by the presence of burrows, scat, sagebrush floret clippings, tracks, and, on rare occasion, observation of individual rabbits. When direct observations of current activity (observation of a rabbit, tracks, urine stains, or floret clippings) were not made, the general condition of pellets directed our assessment of activity. Brown pellets indicated current or active use; tan or somewhat grey pellets indicated the burrow had recently become inactive; and very grey pellets indicated the burrow system was old (Roberts 2001, Ulmschneider 2003). At each hole, we recorded the evidence of activity and marked location information using a GPS.

\section{Sagebrush Site Characteristics:}

In 2005, vegetation measurements were taken for all sagebrush and affiliated shrub species, rabbitbrush (Chrysothamnus nauseousus) and Rocky Mountain juniper (Juniperus scopulorum) (Wambolt \& Frisina 2002, Winward 2004), using the line-intercept sampling method (Canfield 1941, Roscoe pers. comm. 2005). While rabbitbrush and juniper were recorded, they typically represented less 
than one percent of the shrub cover at each survey site.

Two parallel 25-meter long transects, 25 meters apart, were placed in representative portions of areas surveyed for activity. Sampling was performed across all levels of activity, from currently active burrow systems to sites that showed no signs of ever having been used. If burrows were present, at least one transect line was placed so that it intersected at least one hole and its associated vegetation. The height and width of each shrub intersecting the transect were recorded. Each shrub was identified to species and/or subspecies (Wambolt and Frisina 2002, Winward 2004).

\section{Predictive Model:}

We undertook the development of an exploratory predictive model for pygmy rabbit distribution in Beaverhead and Madison Counties by first examining all known point locations for the species in the Montana Natural Heritage Program's Point Observation Database. From these points we defined the extent of the modeling region by a rectangle loosely encompassing West Yellowstone at the eastern boundary, Lost Trail Pass at the western boundary, the farthest southern point in Montana as the southern boundary, and Butte as the boundary to the north.

In order to maintain a high level of data precision, we only used pygmy rabbit locations with a spatial precision of 100 meters or better for development of the model. For the second step, we separated the data into two categories: (1) point locations resulting from Heritage fieldwork in 2004 and 2005 (this project) and (2) all other pygmy rabbit location information contained in the Heritage Point Observation database. With the need to maintain high spatial precision many data points had to be eliminated from the model development dataset. Most of the remaining historic points were collected by Rauscher (1997) in 1996 and 1997.

To limit problems arising from spatial autocorrelation, a one-kilometer grid was overlaid on the broadly defined area encompassing all documented pygmy rabbit burrow locations and one point within each grid cell was randomly chosen to represent points in that location. The distance of one kilometer was selected in accordance with the separation distance defined by the small home range of the species (NatureServe 2005). For purposes of this model, all known pygmy rabbit burrows were treated the same; no distinction was made between active, recent, or old.

Similar to other studies, we investigated elevation, slope, depth to bedrock, clay content, aspect, and vegetation covertype as variables in our models (Katzner \& Parker 1997, Gabler et al. 2000, Rachlow \& Svancara 2003, Simons and Laundre 2004). Aspect explained little about the distribution of point locations and was dropped from all models. We investigated two vegetation layers: (1) the 30 meter resolution GAP Analysis covertype layer (Fisher et al. 1998); and (2) the Southwest Montana Sagebrush Canopy Cover Classification (SILC3) (WSAL 2005). Covertype classes associated with mapping efforts used in our models are shown in Tables 1 and 2.

Values for each of the continuous and categorical variables examined were assigned to the randomly selected points as well as all data gathered during the 2004 and 2005 survey efforts and all known point localities in the Montana Natural Heritage Program's Point Observation Database. Histograms of the distribution of these values were then constructed and compared in order to determine potential biases in values associated with these various sets of documented pygmy rabbit locations (Appendix 3). In developing our model(s) we decided to investigate two separate levels of data-fit: (1) a more "conservative" approach which involved using values of variables that generally fit $70 \%$ of the pygmy rabbit locations, and (2) a more "liberal" approach which involved using values of variables that generally fit $90 \%$ of the data or more. Since covertype information from GAP and SILC3 might differ in ability to predict pygmy rabbit distribution, we decided to apply both of these vegetation covertype classification systems to both the conservative and liberal model designs. Thus, we developed a suite of 4 
models: (1) Conservative Model with GAP covertypes; (2) Liberal Model with GAP covertypes; (3) Conservative Model with SILC3 covertypes; and (4) Liberal Model with SILC3 covertypes.

Table 1. GAP 30 Cover Types

\begin{tabular}{|c|l|}
\hline \hline GAP 30 Attribute Value & Definition \\
\hline \hline 3140 & Low cover grasslands (Upland grasslands) \\
\hline 3150 & Low/moderate cover grasslands (Upland Grasslands \\
\hline 3350 & Big Sage Steppe (Dry Shrubland) \\
\hline 3351 & Mountain Big Sagebrush (Dry Shrubland) \\
\hline
\end{tabular}

Table 2. Southwestern MT Sagebrush Canopy Cover Classification (SILC3)

\begin{tabular}{|c|l|}
\hline Cover class & Description \\
\hline \hline 3130 & very low cover grasslands (10-34\% grass) \\
\hline 3550 & very low cover sagebrush/low cover grass (5-14\% sagebrush \& 10-24\% grass) \\
\hline 3380 & low cover sagebrush (15-24\% sagebrush) \\
\hline 3390 & moderate cover sagebrush (25-34\% sagebrush) \\
\hline
\end{tabular}

Table 3. Variables and Model Components for Pygmy Rabbit Distribution

\begin{tabular}{|l|l|l|l|l||l||}
\hline Variable & Units & $\begin{array}{l}\text { Conservative } \\
\text { GAP30 }\end{array}$ & $\begin{array}{l}\text { Liberal } \\
\text { GAP30 }\end{array}$ & $\begin{array}{l}\text { Conservative } \\
\text { SILC3 }\end{array}$ & $\begin{array}{l}\text { Liberal } \\
\text { SILC3 }\end{array}$ \\
\hline \hline Elevation & meters & $1250-2250$ & $1250-2345$ & $1250-2250$ & $1250-2345$ \\
\hline Slope & degrees & $<=10$ & $<=15$ & $<=10$ & $<=15$ \\
\hline $\begin{array}{l}\text { Depth to } \\
\text { Bedrock }\end{array}$ & centimeters & $>=135$ & $>=1 \mathrm{~m}$ & $>=135$ & $>=1 \mathrm{~m}$ \\
\hline Percent Clay & percent & $=15-25 \%$ & $=15-30 \%$ & $=15-25 \%$ & $=15-30 \%$ \\
\hline GAP30 & $\begin{array}{l}\text { covertype } \\
\text { class } \\
\text { (See Table 1) }\end{array}$ & 3350,3351 & $\begin{array}{l}3350,3351, \\
3150,3140\end{array}$ & none & none \\
\hline SILC3 & $\begin{array}{l}\text { covertype } \\
\text { class } \\
\text { (See Table 2) }\end{array}$ & none & none & 3380,3550 & $\begin{array}{l}3380,3550,3130, \\
3390\end{array}$ \\
\hline
\end{tabular}




\section{RESULTS}

\section{Field Surveys:}

Locating burrows and confirming current activity was aided by the presence of snow at most sites surveyed during the 2004 survey effort. Tracks to and from burrow openings, urine stains, and sagebrush clippings allowed sites to be more easily and confidently characterized as active. The snow was not deep enough to require the rabbits to use subnivean tunnels for movement between burrows and no such tunnels were documented. Only limited, scattered snow was present during the survey effort in 2005 and this forced much more stringent examination of sites to determine activity status. Based upon our experience, we recommend pygmy rabbit surveys be carried out with the presence of some snow cover if at all possible, as it is far easier to locate and assess the activity status of sites under these conditions (Appendix 2).

The historic locations of Horse Prairie, Medicine Lodge Creek (south of Ayers Canyon), Badger Gulch/Sagebrush Creek, and Upper Ermont Creek were identified for survey in 2004, but were inaccessible that year due to deep snow. Because efforts focused in a different geographic area in 2005, these locations were ultimately not visited. These sites should therefore be a high priority for future survey. In 2005, only one previously documented location was resurveyed. All other sites surveyed were considered only potentially inhabitable by pygmy rabbits as the locations were outside their documented range at the time (Roscoe, pers. comm. 2005).

In the following description of sites, a "burrow" may represent one or more hole and may, in some instances, qualify as a burrow complex. We identified individual holes and classified them as a burrow complex if the holes appeared connected. Roberts (2001) described a burrow complex as being comprised of one to seven underground connected holes, with two openings being the most common. If no description is given below for the precise number of holes observed, the burrow consisted of one hole. Our estimate of connectedness was speculative since we did not physically investigate any of the holes. We generally estimated holes to be connected if they were associated with an individual clump of sagebrush or distinctly isolated from another group of holes. Under our classification system, burrow complexes ranged from one to thirty five holes.

\section{SURVEYS}

As noted, field inventory work in 2004 was focused on Beaverhead County. Evidence of current or recent activity was documented in each of the areas of known historic use. A total of 198 burrow complexes were documented, representing a total of 380 burrow entrances. Of these, 231 were associated with current pygmy rabbit activity. The high proportion of active to inactive burrows may be a result of the fact that burrows with current activity are easier to locate because tracks in the snow make them highly apparent. The relative difference in abundance between currently active and recently active should not be interpreted to indicate any level of past versus current activity.

\section{Surveys of Historic Locations}

Five historic locations of pygmy rabbit use were surveyed: Grasshopper Creek, Bannack area, Sheep Corral Gulch, south end of Clark Canyon Reservoir, and Lime Kiln Gulch (Figure 1).

South end of Clark Canyon [T10S R10W S30]: Active and inactive burrows were observed. Of the 22 burrows discovered at this location, four were recorded as active; ten showed signs of recent activity, two were identified as old; and six burrows were recorded as possible, but unconfirmed, pygmy rabbit burrows.

Lime Kiln Gulch [T11S R10W S5 \& S6; T10S R10W S32]: No active pygmy rabbit burrows were found. Of the four openings observed, only one was considered a recently occupied pygmy rabbit burrow (grey pellets nearby). Because of the absence of pellets at the other three openings, they were recorded as possible, but unconfirmed, burrows.

Grasshopper Creek [T7S R12W S9]: Fourteen burrows were observed, and all were active with 
signs of fresh tracks, scat, urine stains, and fresh sagebrush clippings.

Sheep Corral Gulch (east of Badger Gulch) [T9S R12W S10 \& S3]: Twenty-two burrows were observed, 14 were classified as active, four as recent, two as old, and two as undetermined (whether active or inactive).

Bannack Area (north) [T8S R12W S11]: Seven active burrows were observed. Fresh tracks, scat, and sagebrush clippings were evident at each burrow system. A survey within the town of Bannack, where a historic burrow had been recorded, found no evidence of current pygmy rabbit use.

Bannack Area (south) [T8S R12W S22]: Five active burrows were recorded at this site. Fresh tracks, scat, and sagebrush clippings were evident.

\section{Surveys Of Areas Without Previously}

\section{Recorded Activity}

Seven new areas were surveyed following the same protocol as sites with documented historic use under the recommendations of BLM field personnel. These locations were selected because of their similar appearance to sites with known pygmy rabbit activity. All of these locations revealed current pygmy rabbit use and deserve further investigation (Figure 2).

Ermont Area BLM [T7S R10W S6]: Surveys of the Ermont area were undertaken southeast of the historic locality and revealed ten active burrows and two old ones.
Ermont Area State Section [T7S R10W S16]: Six burrows were recorded on this state section; two were active, three had recent activity, and one was old.

Coyote Flats [T7S R10W S16]: Twenty-eight burrows were recorded in this area. Of these, 14 showed signs of current activity; ten were recorded as recent, three as old, and one as undetermined.

Coyote Creek [T9S R13W S32]: A total of 21 burrows were recorded, 19 of which were active. Evidence of activity included fresh tracks, pellets, and sage clippings. Two burrows were described as having recent activity. This area was particularly active and evidence suggested multiple entry holes per burrow system. One complex appeared to have 9 holes (all within 12 meters) and all holes showed current activity.

Medicine Lodge Creek - Kissick Gulch [T11S R12W S11, S12, S13, S14, S36]: Twenty-two burrows were recorded; nine were identified as active; nine as having recent activity; and four as undetermined.

Medicine Lodge Creek - Keystone Gulch (state section) [T11S R12W S36]: Thirteen burrows were identified in this area. Of the total, four were active, with the remaining ones identified as either old or undetermined.

Rape Creek [T10S R13W S1\&S2]: Twentythree burrows were identified. Of this total, ten were active, three were recent, and ten were old. Evidence at this site included fresh tracks, scat, and sage clippings. 


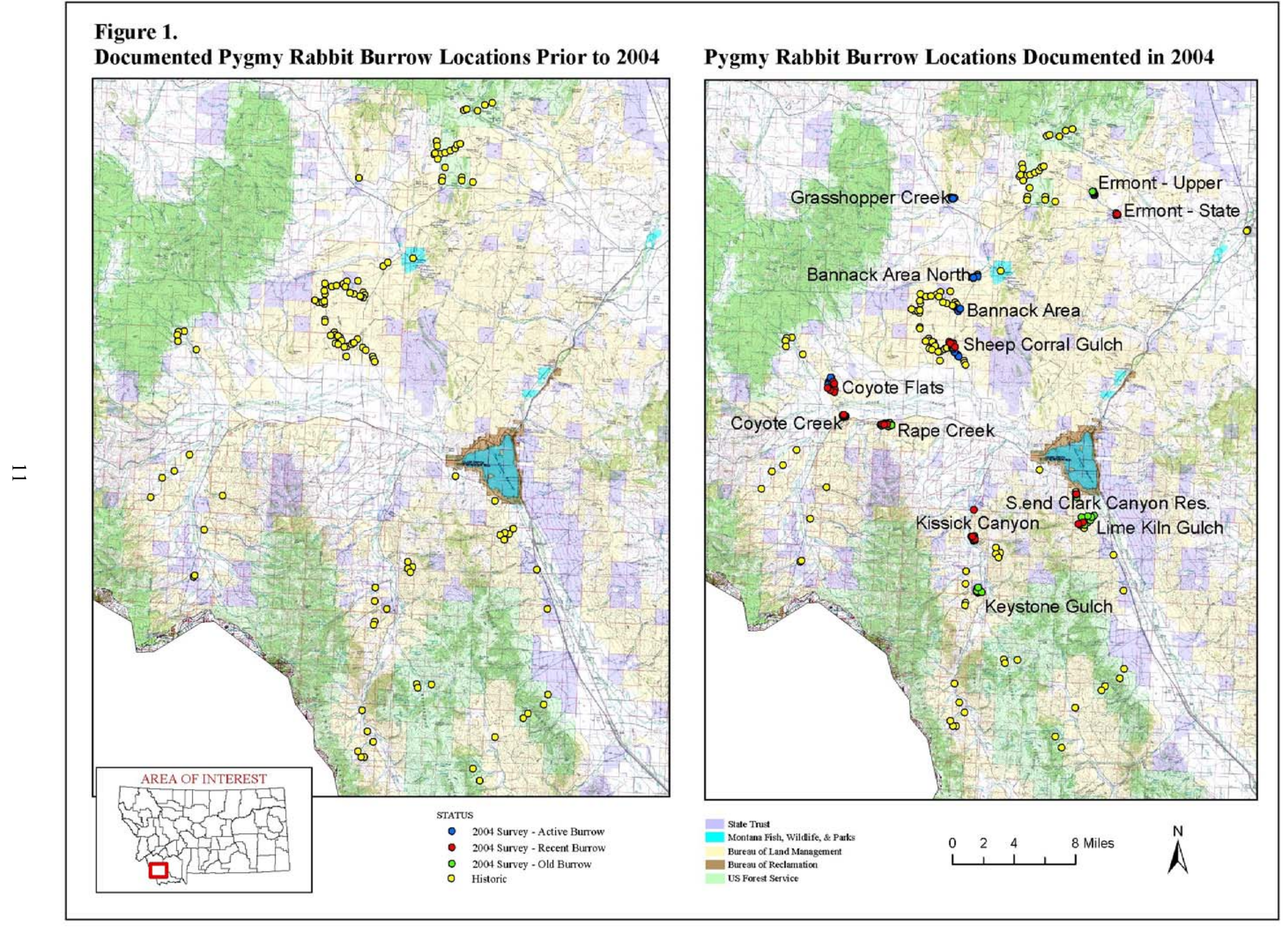




\section{SURVEYS}

The five areas identified in Madison County for survey in 2005 included Sweetwater Basin, Sweetwater Creek, Nevada City-Herman Gulch, Ruby River Reservoir, and Cottonwood Creek (Figure 2). Pygmy rabbit occupation was previously documented at a few locations within Sweetwater Basin, but not in the other locations identified for survey. Field investigations at these locations expanded documented pygmy rabbit occupation northeast of previously recorded areas.

\section{Sweetwater Basin [T8S R6W S34, S36] [T9S R6W S3]}

A total of 215 burrow holes were recorded in the Sweetwater Basin. One hundred seventy-seven were recorded as active, with evidence of one or more of the following features: fresh scat, tracks, urine stains, or sagebrush clippings. Thirty-five holes had recent activity (evidence of grey pellets) and three were old (no pellets, and/or collapsed openings). Many of the burrows were recorded as single holes, but several multipleholed burrow complexes were discovered, one of which contained a collection of 35 active holes.

Sweetwater Creek [T9S R5W S4] [T7S R5W S35] Thirty-three burrow holes were documented; 29 as active and 4 as recent. This site contained the most robust big sagebrush $A$. tridentata (mix of A.t tridentata [basin big sagebrush] and A.t. vaseyena [mountain big sagebrush]) found anywhere during our field investigations. The quantity of pygmy rabbit droppings at this site suggested either long-term habitation or a large local population of pygmy rabbits.

Nevada City-Herman Gulch [T6S R3W S9, S10, S16] A total of 19 holes were discovered. Ten burrow holes were of recent activity (grey scat) and nine were old to very old (no pellets).

Ruby River Reservoir [T7S R4W S20, S21] Seven burrow holes were recorded; one recent with a few tan pellets and six old with a few grey pellets.
Cottonwood Creek - [T7S R5W S35 NW11/4]

Two active holes with presence of brown scat.

\section{Surveys of Locations for Possible Pygmy}

Rabbit Presence

Several sites were surveyed based upon their proximity to documented activity. These sites were located at the edge of the species distribution (Roscoe, pers. comm. 2005). Survey efforts revealed limited to no evidence of pygmy rabbit activity at these new locations.

South and West of Alder [T6S R4W S20 \& T6S R5W S12]. Areas within two sections to the south and west of Alder were surveyed. One occurred on state land [T6S R4W S20] where the presence of tall, dense stands of big sagebrush [A.t.tridentata] appeared suitable for pygmy rabbit use. Surveys in this section revealed a few scattered brown and grey pygmy rabbit pellets as well as mountain cottontail (Sylvilagus nuttallii) pellets that were present for comparison. No holes indicating pygmy rabbit use were discovered. This location is within 12 kilometers of the nearest known active site and may represent evidence of dispersal to, or movement through, the area (Estes-Zumpf 2005). Investigation of a BLM section in this area [T6S R5W S12] revealed an area with lowstature Wyoming big sagebrush (A.t. wyomingensis). No pygmy rabbit use was observed in this area.

Barton Gulch [T7S R4W S17 SE $1 / 4$ ] No evidence of pygmy rabbit use was recorded in this area. The site contained thick stands of A.t.tridentata (1-2 meters tall) and provided what appeared to be appropriate habitat. Although cottontail pellets were evident, no sign of pygmy rabbits was observed.

East of Laurin [T5S R4W S34 SE $1 / 4$ of NW 1/4 ]. This quarter-quarter section lies north of a dirt road leading east from Laurin. This site contained more decadent big sagebrush [A.t.tridentata] and grass cover than other areas with documented pygmy rabbit activity. The southern half of the section contained limited sagebrush cover and, considering the topography, was not surveyed. Private lands 
encircle the BLM lands with scattered sagebrush stringers in lower-lying areas of the surrounding landscape. No evidence of pygmy rabbit use was recorded at this site.

Investigations into the Robb Ledford Wildlife Management Area revealed very limited to no sagebrush cover. We investigated the few areas of public access with sagebrush cover south of the Ruby River [T9S R4W] and into the Robb Ledford WMA, but discovered no pygmy rabbit activity. Given the lack of available sagebrush cover, we estimate the western boundary of the Robb Ledford WMA represents the limit of distribution of pygmy rabbits in this area of Madison County. Indeed, this area was not identified as potential pygmy rabbit habitat by any of the predictive models we examined (see section below entitled Development of the Predictive Model). 


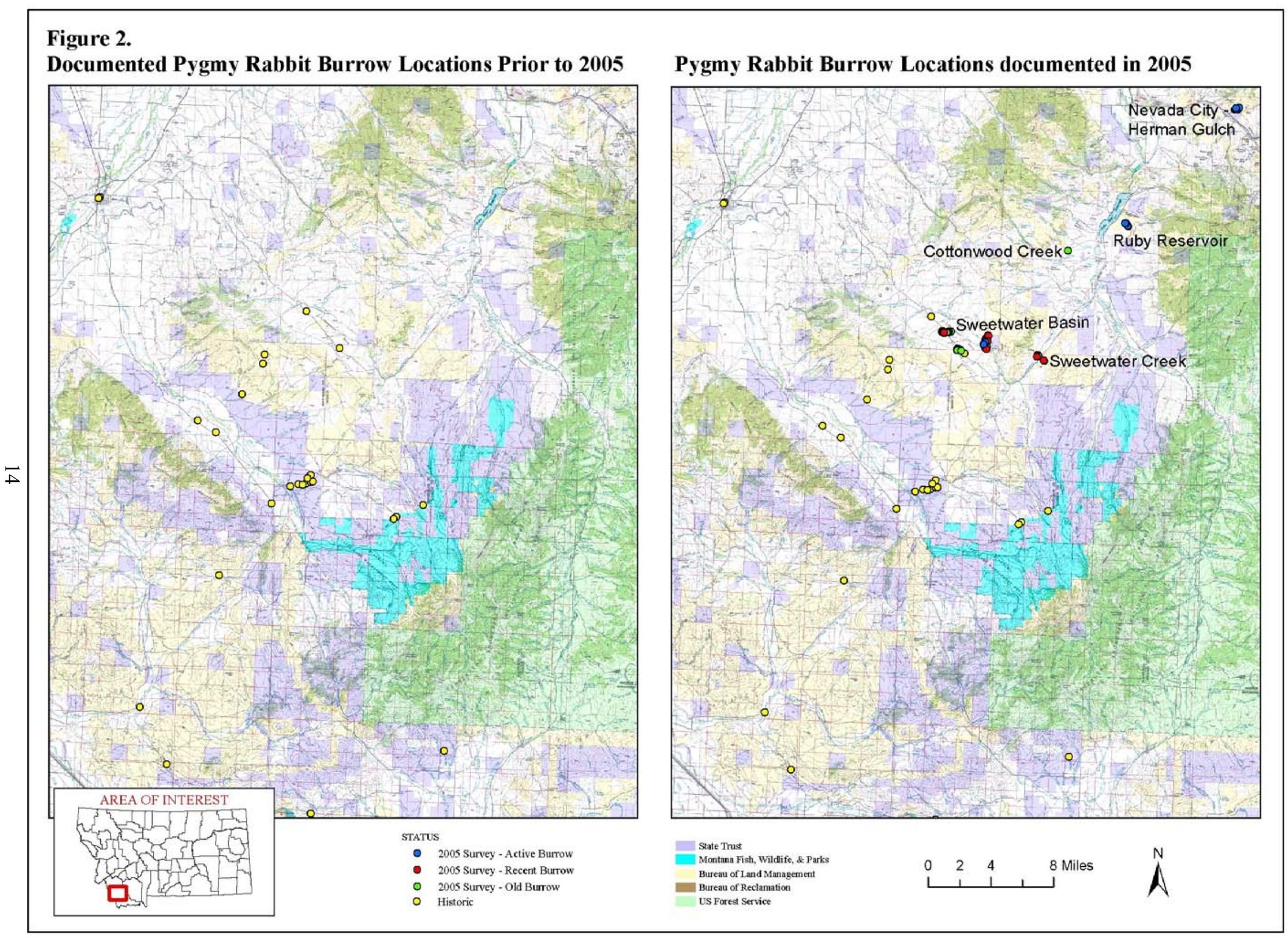




\section{Figure 3.}

Documented Pygmy Rabbit Burrow Locations: 2004 \& 2005 Site Locations Identified

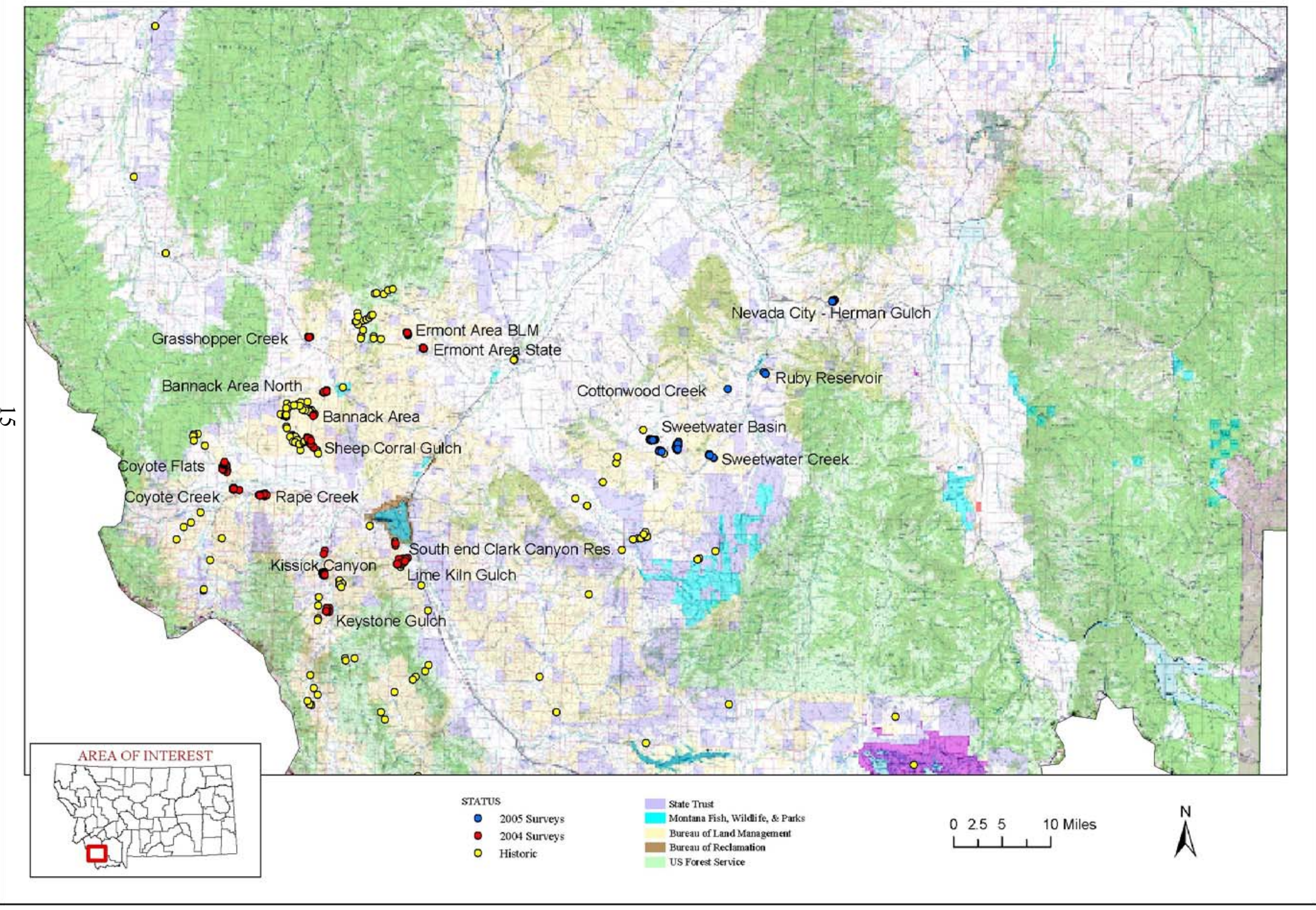


Sagebrush Site Characteristics:

Big sagebrush (A.tridentata) was the most dominant plant species at each of the sites surveyed, with Basin big sagebrush (A.t.tridentata) and mountain big sagebrush (A.t.vaseyena) the most commonly encountered subspecies. The overall cover across all sites we surveyed ranged from 21.9 to 32.4 percent (Table 4). These values are generally greater than that of Rauscher's (1997) study (21.3 percent), but fell within that documented in other states; mean sagebrush cover in Washington (32.7 percent) (Rauscher 1997), Oregon (23.7 percent) (Weiss \& Verts 1984), and Idaho (19 percent) (Green \& Flinders 1980).

The most apparent difference between sites without pygmy rabbit occupation and those with documented activity was plant species composition. The sites without pygmy rabbit activity possessed nearly twice the coverage of A.t.tridentata as the sites with documented activity (Table 5). A.t.vaseyena cover on sites without observed pygmy rabbit activity was equal to or less than one third of the total shrub cover of sites with evidence of pygmy rabbit occupation (Table 5). Rabbitbrush was present (between four and five percent cover) at sites with documented activity while sites without evidence of pygmy rabbits were absent of rabbitbrush. The percent cover of shrubs at the sites without pygmy rabbits falls within the range of the values for active to recent sites, and the overall mean height of the sites without pygmy rabbits was equal to sites identified as recently active.

While Rauscher (1997) calculated mean vegetation height at 0.37 meters, our values for overall mean height ranged from $0.52 \mathrm{~m}$ to 0.87 $\mathrm{m}$. Our estimates are more similar to work done in Washington (0.82 m) (Rauscher 1997), Idaho (0.56 m) (Green \& Flinders 1980), and Oregon (0.91 m) (Weiss \& Verts 1984) (Table 6).

Table 4. Results of Vegetation Measurements During 2005 Field Surveys

\begin{tabular}{|c|c|c|c|}
\hline \multicolumn{4}{|c|}{ Overall Shrub Characteristics } \\
\hline \multirow{2}{*}{$\begin{array}{l}\text { Burrow } \\
\text { Activity }\end{array}$} & Mean \% Cover & Overall Mean Height & \multirow{2}{*}{ \# of transects } \\
\hline & $\begin{array}{l}\text { mean \% in meterss (standard deviation) } \\
\text { [min/max \% of cover of transects] }\end{array}$ & $\begin{array}{l}\text { mean in meters (standard deviation) } \\
\text { [min/max of mean height of transects] }\end{array}$ & \\
\hline Active & $\begin{array}{c}24.9 \%(12.4) \\
{[3.6 / 58.4]}\end{array}$ & $\begin{array}{c}0.62(0.17) \\
{[0.4 / 1.21]}\end{array}$ & 50 \\
\hline Recent & $\begin{array}{l}32.4 \%(6.8) \\
{[21.9 / 41.2]}\end{array}$ & $\begin{array}{c}0.75(0.23) \\
{[0.4 / 1.07]}\end{array}$ & 12 \\
\hline Old & $\begin{array}{l}21.9 \%(5.3) \\
{[14.7 / 30.0]}\end{array}$ & $\begin{array}{l}0.63(0.18) \\
{[0.33 / 0.94]}\end{array}$ & 10 \\
\hline Null & $\begin{array}{l}29.3 \%(9.4) \\
{[16.7 / 50.4]}\end{array}$ & $\begin{array}{l}0.75(0.13) \\
{[0.58 / 0.94]}\end{array}$ & 10 \\
\hline
\end{tabular}


Table 5. Shrub species composition of sites by activity status

\begin{tabular}{||l||c|c|c||c||}
\hline \multicolumn{5}{|c|}{ Relative Shrub Cover } \\
\hline $\begin{array}{l}\text { Plant } \\
\text { species }\end{array}$ & $\begin{array}{c}\text { Active } \\
\text { burrows }\end{array}$ & $\begin{array}{c}\text { Recent } \\
\text { burrows }\end{array}$ & Old Burrows & $\begin{array}{c}\text { No Burrows } \\
\text { Present }\end{array}$ \\
\hline \hline A.t. vaseyena & $51.2 \%$ & $34.0 \%$ & $50.6 \%$ & $11.8 \%$ \\
\hline $\begin{array}{l}\text { A.t. tridentata } \\
\text { A.t. unknown (dead) }\end{array}$ & $41.4 \%$ & $57.3 \%$ & $43.2 \%$ & $81.2 \%$ \\
\hline $\begin{array}{l}\text { Rabbitbrush } \\
\text { (Chrysothamnus } \\
\text { nauseousus) }\end{array}$ & $3.1 \%$ & $2.3 \%$ & $0.6 \%$ & $4.9 \%$ \\
\hline $\begin{array}{l}\text { Rocky Mountain } \\
\text { Juniper } \\
\text { (Juniperus scopulorum) }\end{array}$ & $4.3 \%$ & $4.5 \%$ & $5.6 \%$ & - \\
\hline $\begin{array}{l}\text { A.t. tripartita } \\
\text { Total }\end{array}$ & - & $1.9 \%$ & - & $0.2 \%$ \\
\hline
\end{tabular}

Table 6. Mean height of shrub species by activity status

\begin{tabular}{|c|c|c|c|c|}
\hline \multicolumn{5}{|c|}{ Mean height in meters [min/max] } \\
\hline $\begin{array}{l}\text { Plant } \\
\text { species }\end{array}$ & $\begin{array}{c}\text { Active } \\
\text { burrows }\end{array}$ & $\begin{array}{c}\text { Recent } \\
\text { burrows }\end{array}$ & Old Burrows & $\begin{array}{l}\text { No Burrows } \\
\text { Present }\end{array}$ \\
\hline A.t. vaseyena & $\begin{array}{c}0.58 \\
{[0.10 / 1.4]}\end{array}$ & $\begin{array}{c}0.52 \\
{[0.12 / 0.93]}\end{array}$ & $\begin{array}{c}0.59 \\
{[0.17 / 1.04]}\end{array}$ & $\begin{array}{c}0.56 \\
{[0.16 / 1.21]}\end{array}$ \\
\hline A.t. tridentata & $\begin{array}{c}0.74 \\
{[0.10 / 2.3]}\end{array}$ & $\begin{array}{c}0.87 \\
{[0.19 / 1.93]}\end{array}$ & $\begin{array}{c}0.80 \\
{[0.18 / 1.47]}\end{array}$ & $\begin{array}{c}0.77 \\
{[0.20 / 1.38]}\end{array}$ \\
\hline $\begin{array}{l}\text { A.t. unknown } \\
\text { (dead) }\end{array}$ & $\begin{array}{c}0.47 \\
{[0.21 / 0.73]}\end{array}$ & $\begin{array}{c}0.52 \\
{[0.19 / 1.13]}\end{array}$ & $\begin{array}{c}0.3 \\
{[0.3]}\end{array}$ & $\begin{array}{c}0.73 \\
{[0.3 / 0.3]}\end{array}$ \\
\hline Rabbitbrush & $\begin{array}{c}0.45 \\
{[0.17 / 0.90]}\end{array}$ & $\begin{array}{c}0.53 \\
{[0.19 / 0.78]}\end{array}$ & $\begin{array}{c}0.35 \\
{[0.16 / 0.60]}\end{array}$ & - \\
\hline Juniper & - & $\begin{array}{c}1.45 \\
{[1.44 / 1.48]}\end{array}$ & - & $\begin{array}{c}2.36 \\
{[2.36]}\end{array}$ \\
\hline A.t. tripartita & - & - & - & $\begin{array}{c}0.36 \\
{[0.19 / 0.52]}\end{array}$ \\
\hline
\end{tabular}




\section{Predictive Models:}

A total of 403 documented pygmy rabbit locations were utilized in the development and testing of our model(s) and represented both historic data and data gathered recently by the Montana Natural Heritage Program. Since we surveyed areas with the highest likelihood of presence and used only positive data to develop our model, our effort only represents an exploratory step in model design. A more thorough approach to predictive modeling would involve surveying randomly selected sites in order to test the predictive accuracy of presence as well as absence of pygmy rabbits. (All maps of modeling effort are presented in Appendix 1).

Overall the liberal models had higher accuracy in predicting known pygmy rabbit locations than the conservative models and models using the SILC3 vegetation covertypes were more accurate than models using the Gap30 covertypes (Table 7). Although the SILC3 models were generally more accurate than the GAP30 models (Table 7), it must be noted that SILC3 was represented by two cover types (low cover grasslands and low cover sagebrush/low cover grasslands) which are not considered suitable habitats for the species. Two other cover types in the SILC3 classification system that better represent sage cover (moderate cover sagebrush (25-34\% sagebrush) and high cover sagebrush (>35\% sagebrush)) were not identified as explaining known point locations. The conservative GAP model resulted in lower accuracy than the conservative SILC3 when applied across all points, but unlike SILC3, did consist of sage specific cover types (basin big sage and mountain big sage). Thus, in general both vegetation covertype schemes poorly represented known areas of pygmy rabbit distribution. Therefore, while field testing these models in the future, it would be extremely helpful to field test the accuracy of the vegetation layers to see how much the accuracy of those layers contributed to the over-all accuracy of the model (Simons \& Laundre 2004).
Table 7. Model Fit

\begin{tabular}{|l|c|}
\hline \multicolumn{1}{|c|}{ MODEL } & $\begin{array}{c}\text { Percent } \\
\text { accuracy }\end{array}$ \\
\hline \hline Conservative GAP30 & $38 \%$ \\
\hline Liberal GAP30 & $85 \%$ \\
\hline Conservative SILC3 & $50 \%$ \\
\hline Liberal SILC3 & $93 \%$ \\
\hline
\end{tabular}

While the liberal models did have higher accuracy in predicting known pygmy rabbit locations, it is important to consider that because these models are so sweeping in coverage, they may be inappropriate for identifying areas absent of pygmy rabbits.

In to understand the contribution of vegetation cover types to the models, and because the training dataset included cover types known to be unsuitable for pygmy rabbit occupation (Appendix 1), we ran the liberal model with vegetation cover types in the SILC3 classification system which were known to be suitable for pygmy rabbits: moderate cover sagebrush and high cover sagebrush. We selected SILC3 for application, rather than GAP, because this classification project was developed specifically to re-classify sagebrush cover type groups in southwestern Montana (WSAL 2005). Unfortunately, this model correctly predicted pygmy rabbit presence at only seven percent of the data points. In short, as in any predictive GIS based habitat model, accurate data on the distribution of a species key habitat is essential (Simons \& Laundre 2004). Unfortunately, this level of accuracy is lacking at this point in time.

Little is gained by developing models that fit the data well only because their parameters are broad enough to include all known points of distribution. Thus, we suggest that pygmy rabbit conservation would best be served by both field-testing our models and acquiring more accurate information on vegetation cover types so that management efforts can be focused on sites with the highest probability of presence. 


\section{CONCLUSION}

Our field investigations revealed new areas of occupation in Beaverhead County. Furthermore, newly discovered locations in Madison County expanded the known distribution of the species northeast of where they had been documented previously. We located areas of current activity as well as those of recent or old use, and anticipate that future surveys efforts in both counties will reveal additional areas of occupation. Considering the fragmented nature of the landscape (roads, human habitation, and agriculture) and continued activities focused on sagebrush removal, there is a great need to better understand: (1) the connectivity of populations within Montana and between populations in Montana and Idaho); (2) how dispersal of individuals effects local populations, and; (3) the viability of populations in Montana. Thus, there is a need for continued and expanded pygmy rabbit research in Montana.

Our fieldwork found the highest level of pygmy rabbit activity to be associated with the tallest, densest sagebrush site. However, we also documented occupation in areas of lower density sagebrush. Thus, additional work needs to be conducted to identify the difference between high quality and marginal habitat and the contributions of each to the conservation of the species. Without this on-the-ground effort and improved accuracy of vegetation cover types, efforts to understand distribution of the species will continue to be limited.

It is probable that pygmy rabbits select areas for occupation at a scale much finer than that used to develop our GIS models (Gabler et al. 2000), but our models should prove useful in identifying areas worthy of future investigation. However, given the apparent inaccuracies of the cover type classifications, local knowledge of vegetation coverage should be used in concert with the models presented here during future survey efforts. Given the coarse scale of each of the variables used to develop our models, we feel more confident our models identify areas of potential occupation rather than those absent of activity. In conjunction with future surveys, increased accuracy in mapping of vegetation cover types will allow future predictive modeling attempts to be more successful at clearly identifying areas of both suitable and unsuitable habitat and will, therefore, make a much greater contribution to the conservation of the species in Montana. 


\section{CITATIONS}

Canfield, R. H. 1941. Application of the line interception method of sampling range vegetations. Journal of Forestry 39: 388-394.

Estes-Zumpf, W.A. and J.L. Rachlow 2005. Natal Dispersal of Juvenile Pygmy Rabbits: Preliminary Results. Department of Fish and Wildlife Resources, University of Idaho, Moscow, ID. Presentation during The Montana Chapter of The Wildlife Society, Annual Conference. Helena, Montana. March 2, 2005.

Fisher, F. B. , J. C. Winne, M.M. Thornton, T.P. Tady, Z. Ma, M.M. Hart, R.L. Redmond. 1998. Montana Land Cover Atlas. Unpublished report. Montana Cooperative Wildlife Research Unit, The University of Montana, Missoula. viii +50 pp.

Gabler, K.I., J.W. Laundre, and L.T. Heady. 2000. Predicting the Suitability of Habitat in Southeast Idaho for Pygmy Rabbits. Journal of Wildlife Management. 64(3):2000.

Green, J.S. and J.T. Flinders. 1980. Habitat and Dietary Relationships of the Pygmy Rabbit. Journal of Range Management 33 (2): 136-142.

Heady, L.T., K.I. Gabler, and J.W. Laundre. 2001. Habitat Selection by Pygmy Rabbits in Southeast Idaho. BLM Technical Bulletin No. 01-7.

Katzner T.E. and K.L. Parker. 1997. Vegetative Characteristics and Size of Home Ranges Used By Pygmy Rabbits (Brachylagus idahoensis) During Winter. Journal of Mammalogy, 78(4):1063-1072.

NatureServe. 2005. Online search for element information on population/occurrence delineation of pygmy rabbit (Brachylagus idahoensis). http://www.natureserve.org. April 2005.

Montana Natural Heritage Program. 2004. Montana Animal Species of Concern. MTNHP \& MFWP. Helena, Montana. 13 pp.
MTNHP POD. 2005. Point Observation Database. Montana Natural Heritage Program, Helena, Montana. May 17, 2005.

Rachlow, J. and L. Svancara. 2003. Pygmy Rabbit Habitat in Idaho. Idaho State office of the Bureau of Land Management, Boise, Idaho. 28pp.

Roberts, H.B. 2001. Survey of Pygmy Rabbit Distribution, Number and Habitat Use in Lemhi and Custer Counties. BLM Technical Bulletin. No 01-11.

Roscoe, James. 2005. Wildlife Biologist Dillon Field Office Bureau of Land Management. Personal Communication. January 2005.

Simons, E.M. and J. W. Laundre. 2004. A Large-Scale Regional Assessment of Suitable Habitat for Pygmy Rabbits in Southwestern Idaho. Northwest Science, Vol. 78, No.1: 33-41.

Rauscher, R. 1997. Status and Distribution of the Pygmy Rabbit in Montana. Montana Fish, Wildlife, and Parks. 19 pp. plus appendices.

Ulmschneider, Helen. 2003. Surveying for Pygmy Rabbits. Owyhee Field Office Bureau of Land Management. Unpublished documentinitial draft April 2003. 10 pp.

USFWS. 2003. Endangered and Threatened Wildlife and Plants; Final Rule to List the Columbia Basin Distinct Population Segment of the Pygmy Rabbit (Brachylagus idahoensis) as Endangered . Federal Register: March 5, 2003 (Volume 68, Number 43)] Page 10388-10409.

Wambolt, C.L. and M.R. Frisina. 2002. Montana Sagebrush Guide. Montana Department of Fish, Wildlife, \& Parks. 71 pp.

Washington Department of Wildlife. 1993. Status of the pygmy rabbit (Brachylagus idahoensis) in Washington. Washington Department of Wildlife, Olympia.

Weiss N.T. and B.J. Verts. 1984. Habitat and distribution of pygmy rabbits (Sylvilagus 
idahoensis) in Oregon. Great Basin Naturalist 44:563-571.

WSAL. 2005. Online access to the Wildlife Spatial Analysis Lab at the University of Montana. http://www.wru.umt.edu/. May 2005.
Winward, A.H. 2004. Sagebrush of Colorado, Taxonomy, Distribution, Ecology \& Management. Colorado Division of Wildlife. Department of Natural Resources, Denver, CO. $45 \mathrm{pp}$. 

APPENDICES 


\section{Appendix 1. Data Output for Model Development}

\section{Data Output 1. Percent Clay}

Heritage Points 2004-2005

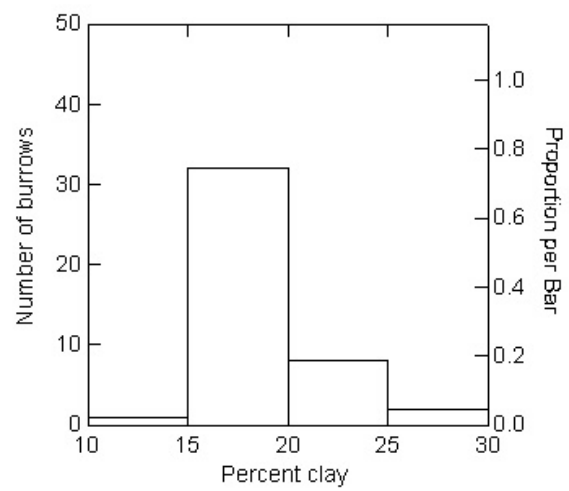

Historic Points (POD)

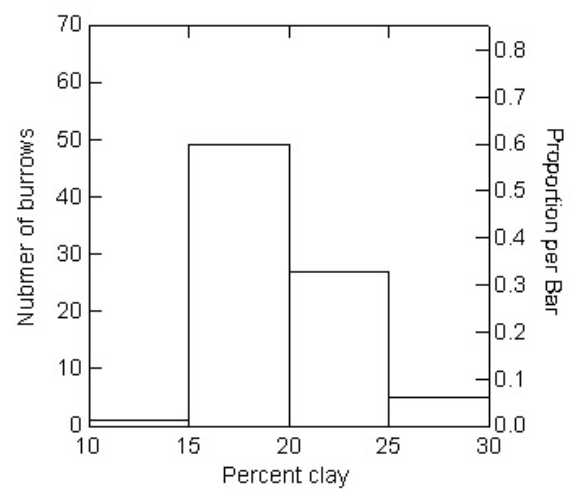

All points

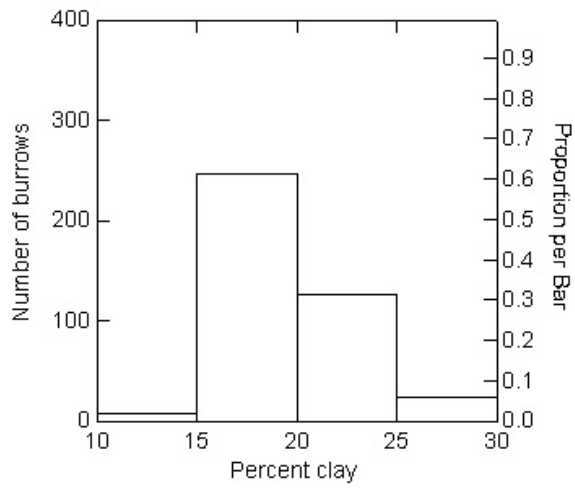




\section{Data Output 2. Slope}

Heritage Points 2004-2005

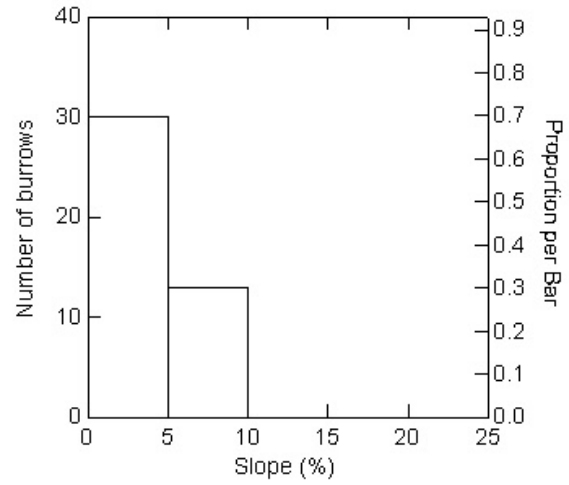

Historic Points (POD)

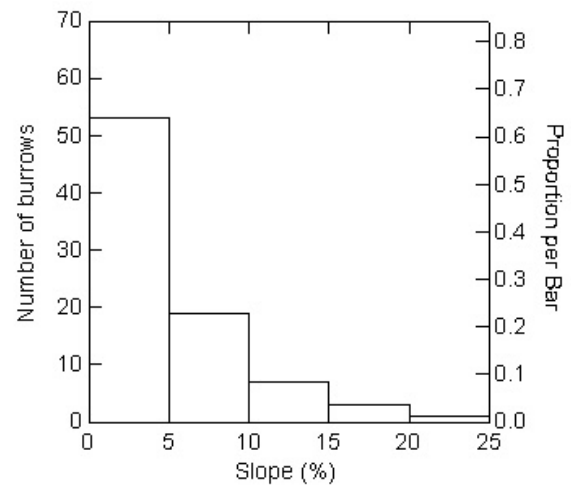

All Points

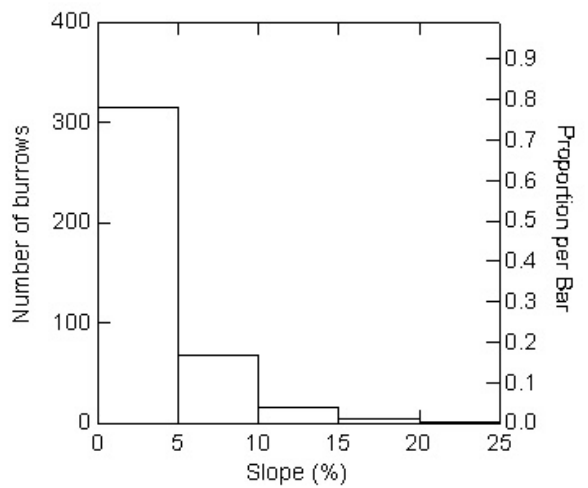




\section{Data Output 3. Elevation}

Heritage Points 2004-2005

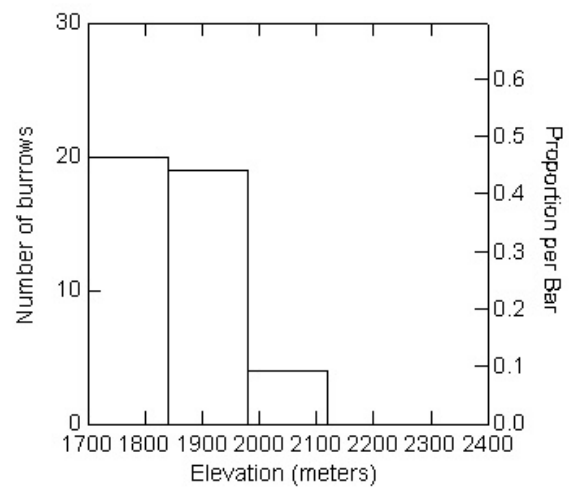

Historic Points (POD)

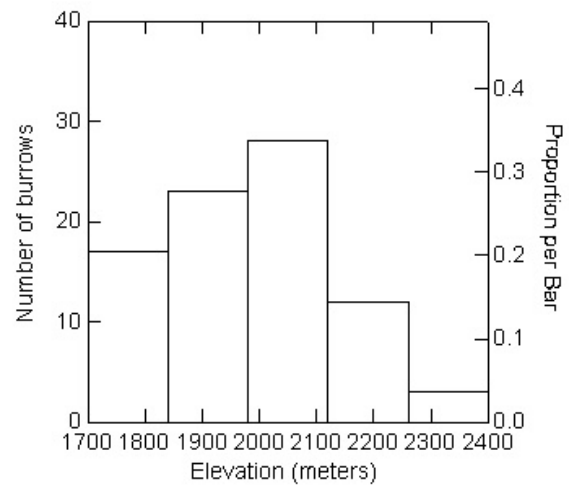

All Points

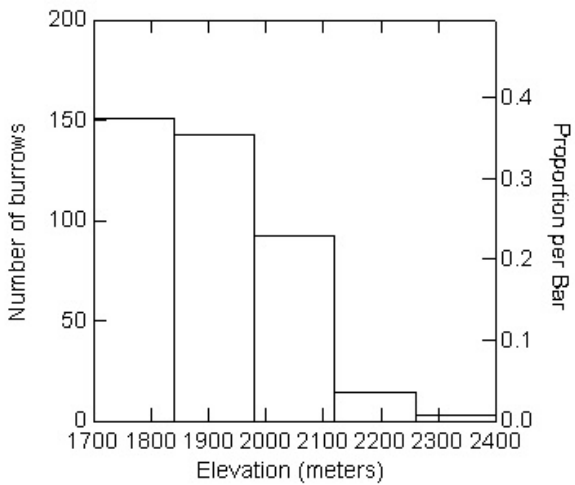




\section{Data Output 4. Depth to Bedrock}

Heritage Points 2004-2005

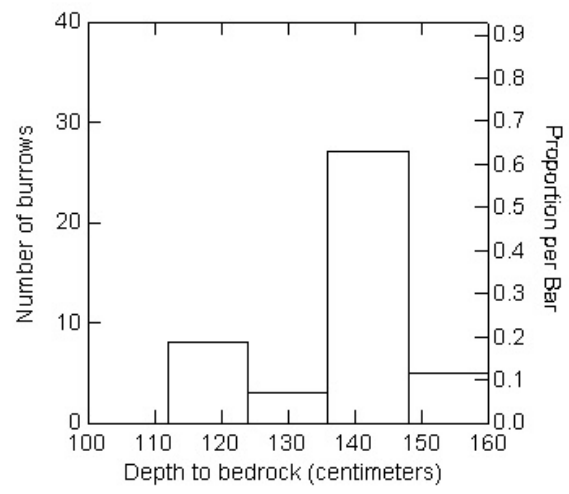

Historic Points (POD)

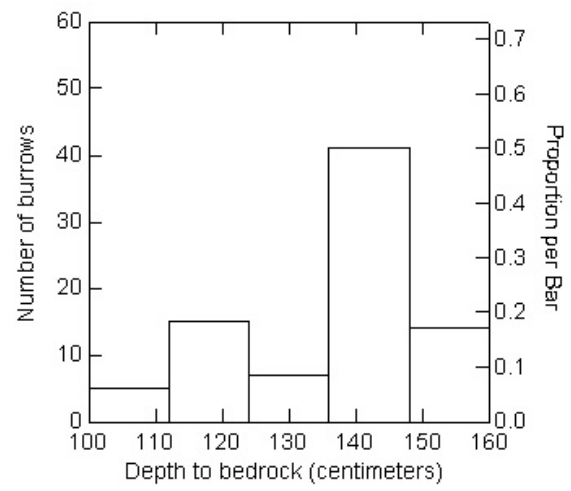

All Points

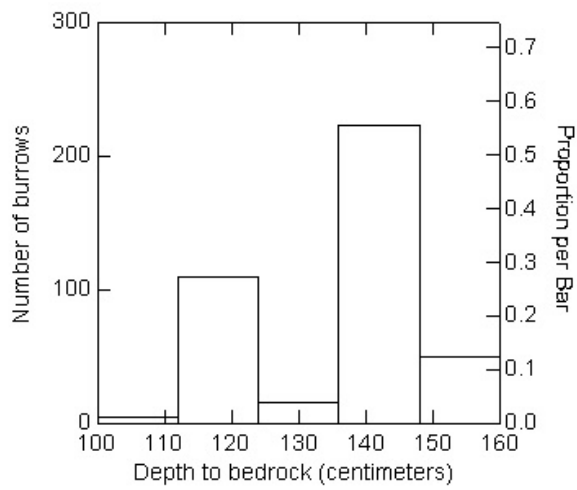


Data Output 5. GAP30 cover types

Heritage Points 2004-2005

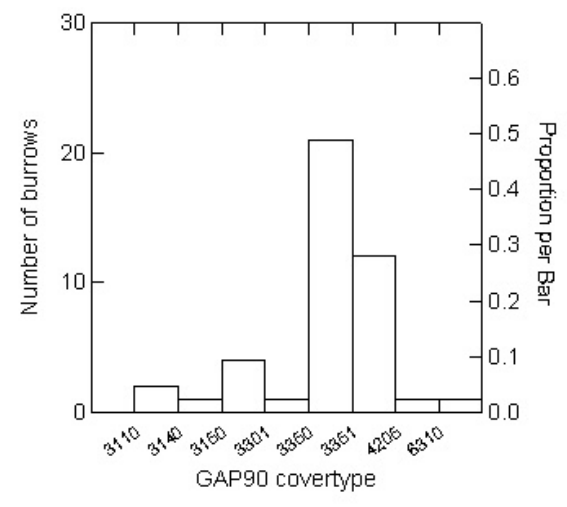

Historic Points (POD)

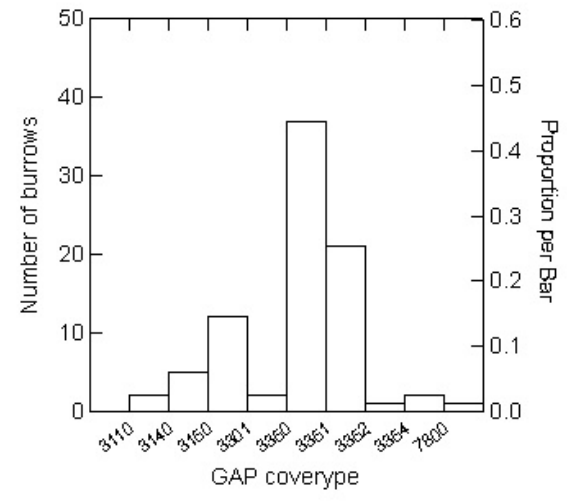

All points

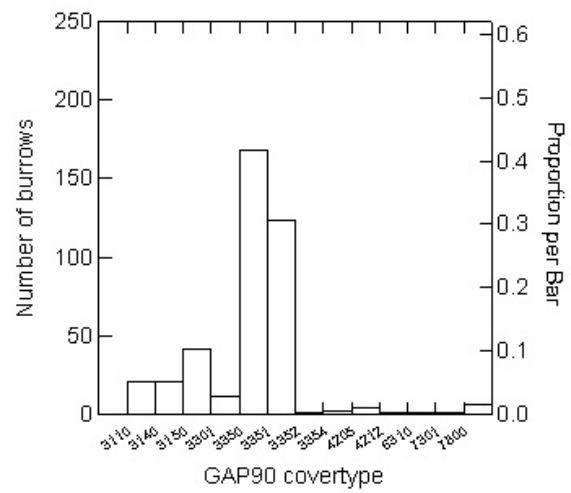


Data Output 6. SILC3 cover types

Heritage Points 2004-2005

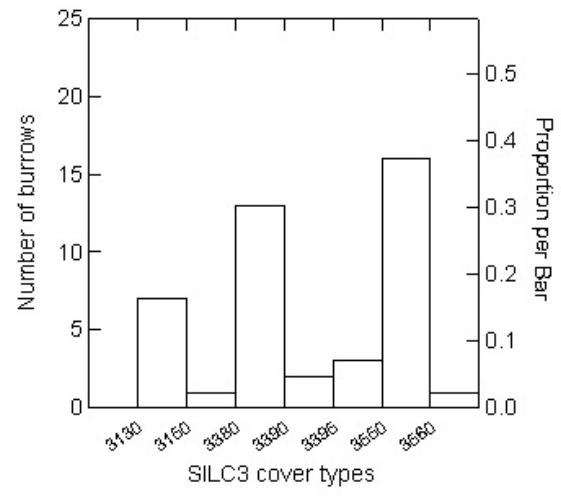

Historic Points (POD)

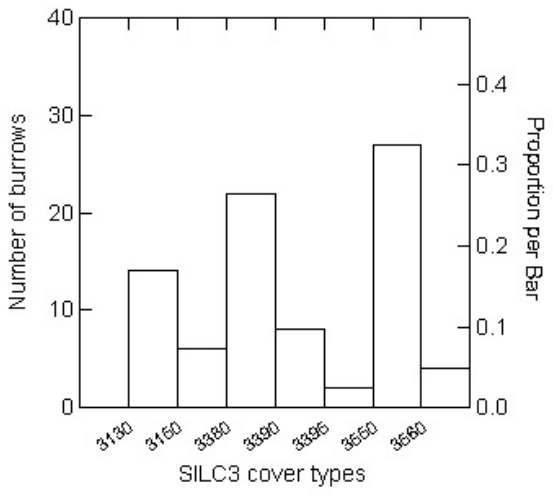

All Points

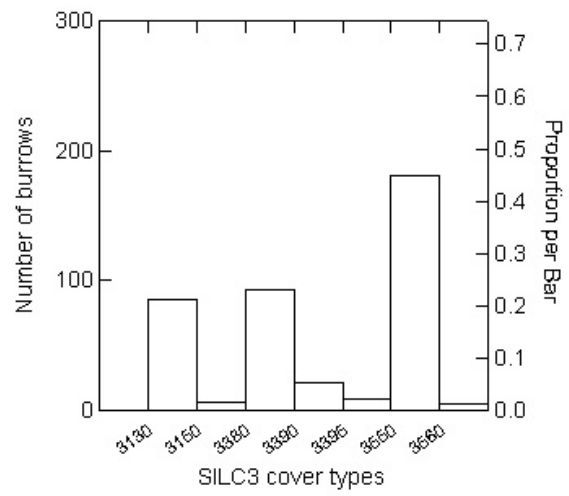




\section{Appendix 2: Photos}

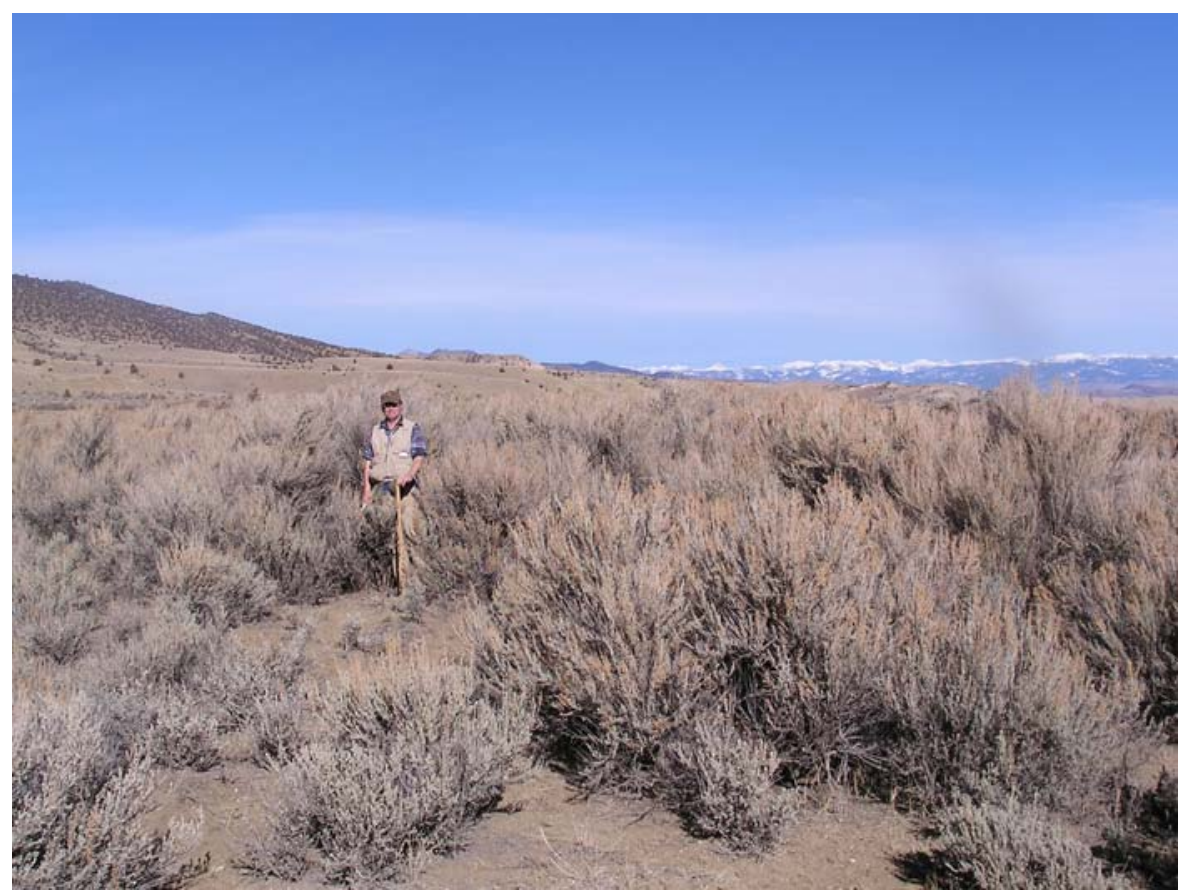

Photo 1. Sweetwater Creek

The most robust Artemisia tridentata on the areas surveyed. Active burrows were discovered at this location and one pygmy rabbit was observed.

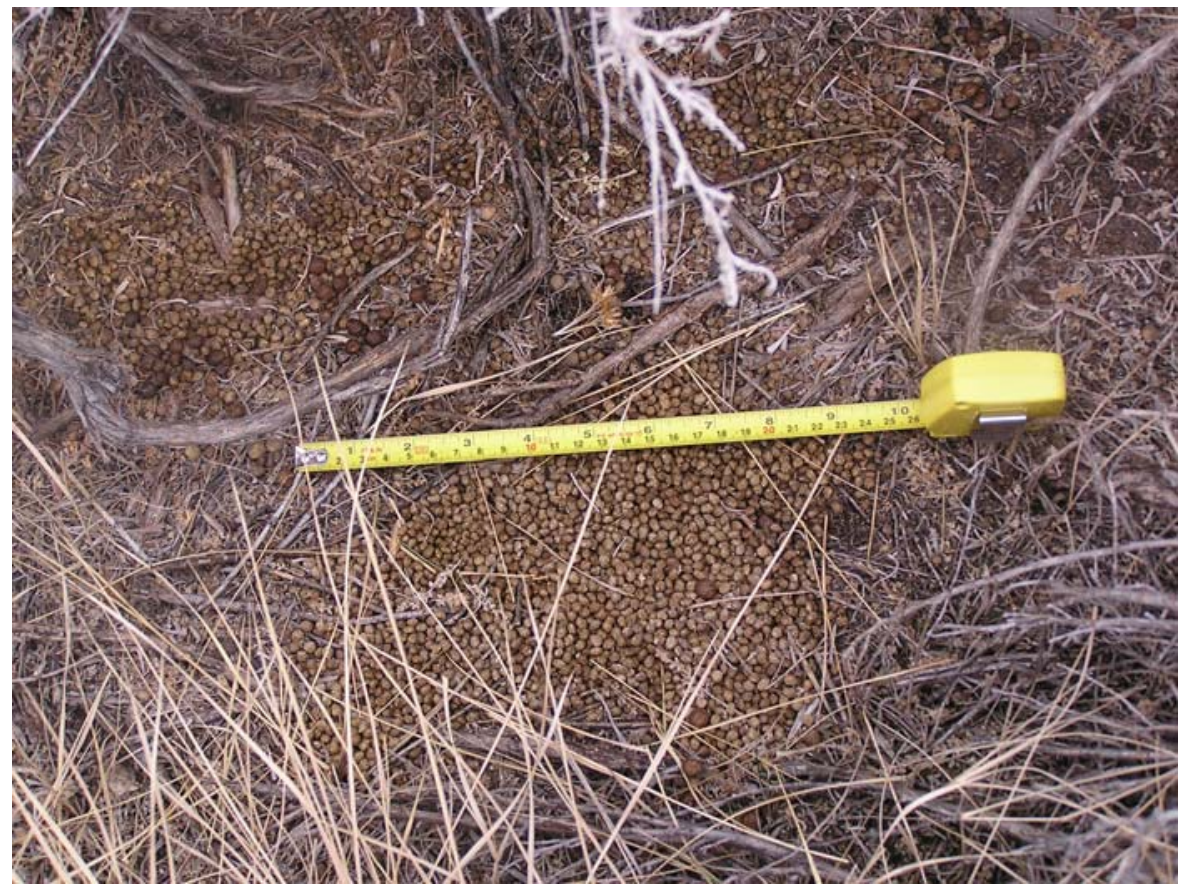

\section{Photo 2. Pellet Pile - Sweetwater Creek}

Evidence of high use and/or numerous pygmy rabbits at this site. Larger cottontail pellets are present in photo. 


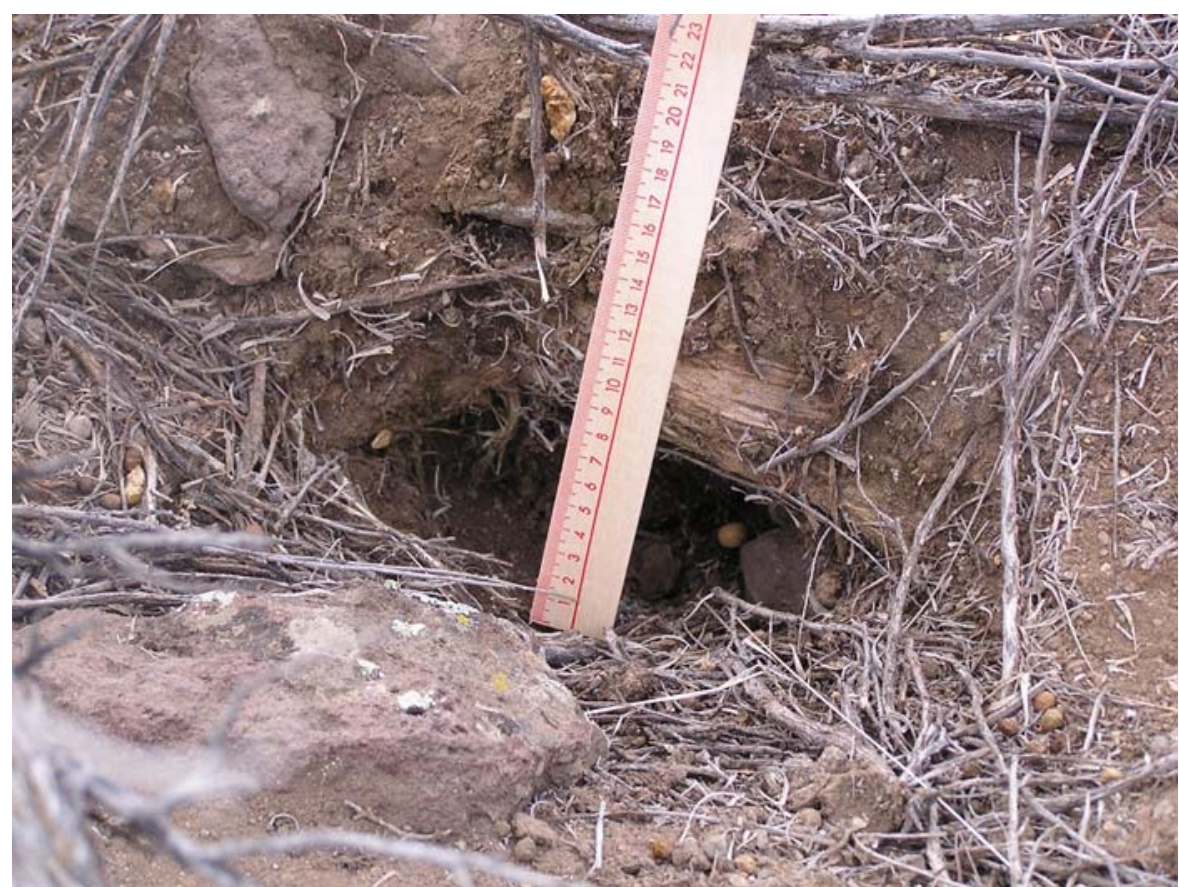

Photo 3. Example of pygmy rabbit burrow hole, note droppings at margins.

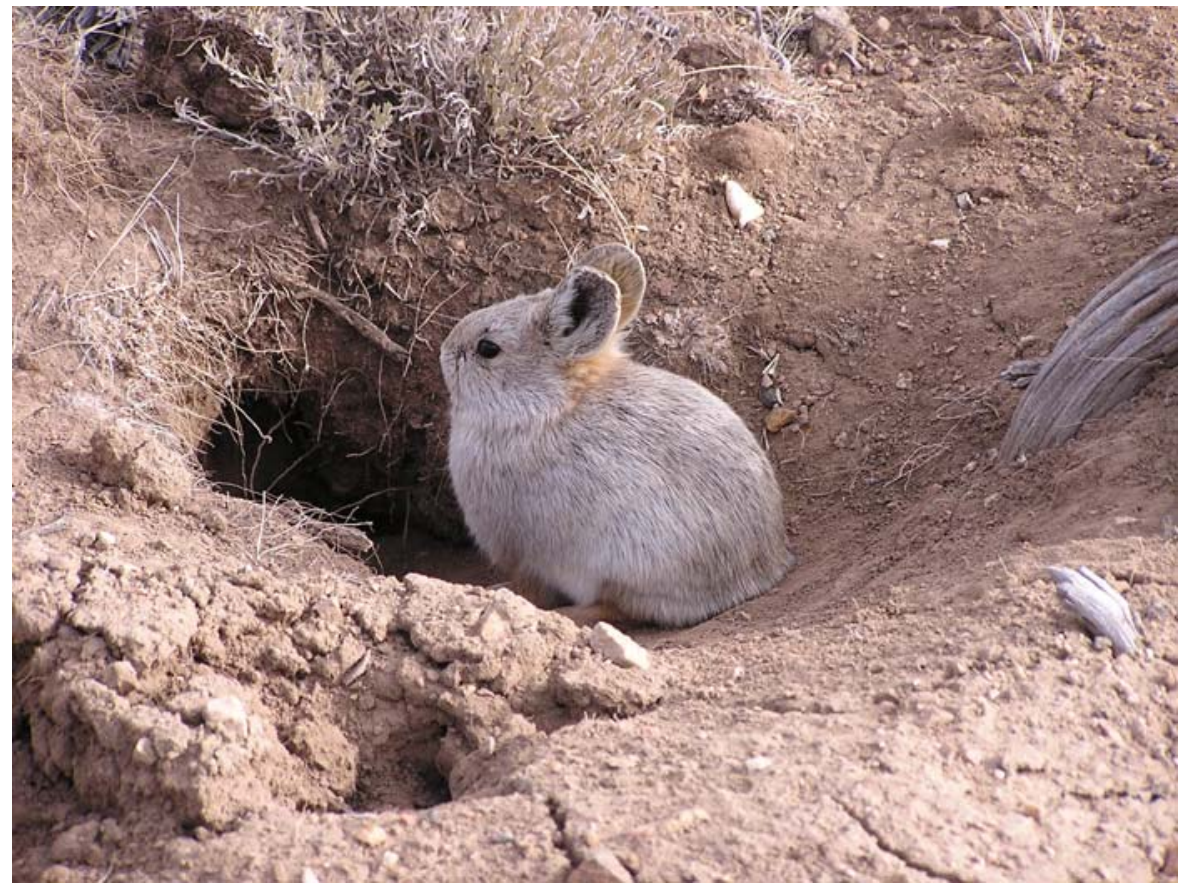

Photo 4. Pygmy rabbit at burrow entrance at Sweetwater Basin.

Although numerous burrows were found at this location, only one individual was observed. 


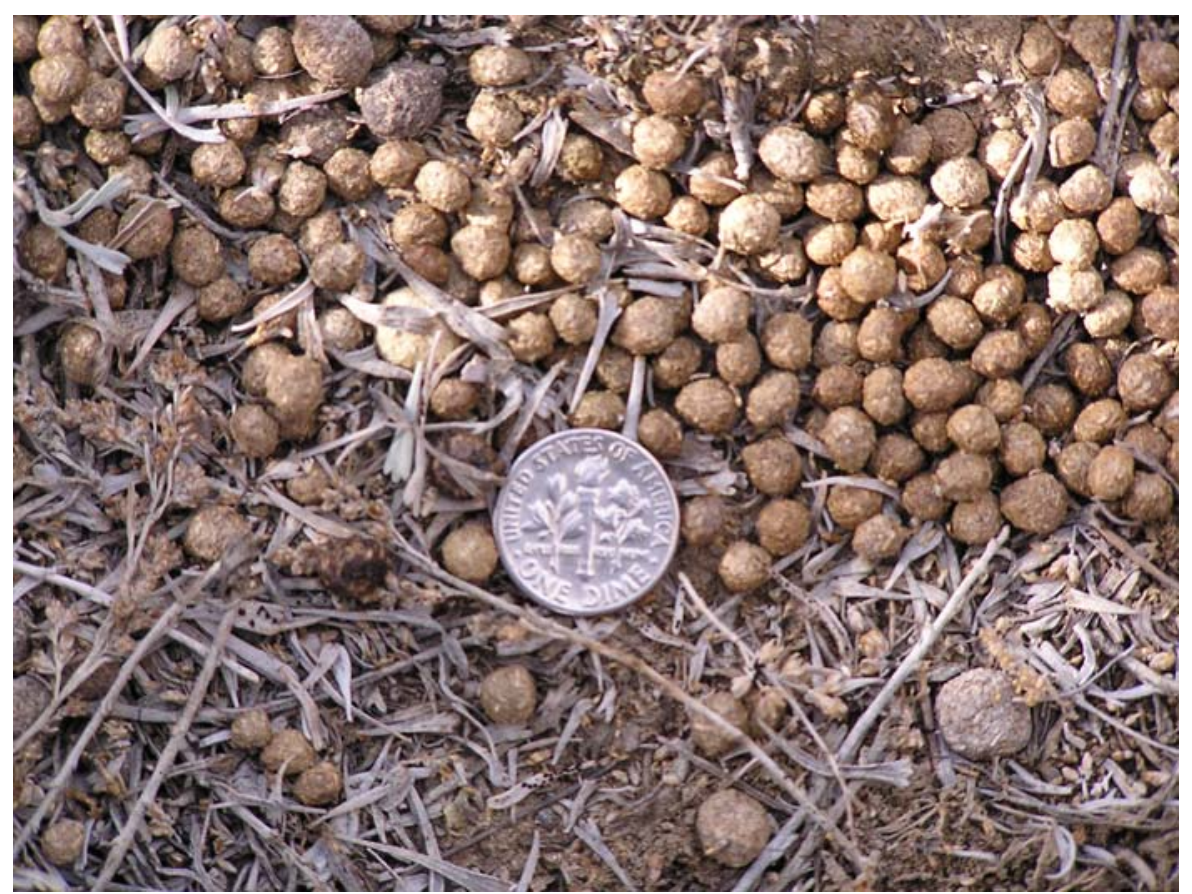

Photo 5. Size comparison of pygmy rabbit droppings.

Note larger cottontail pellets at top left and bottom right.

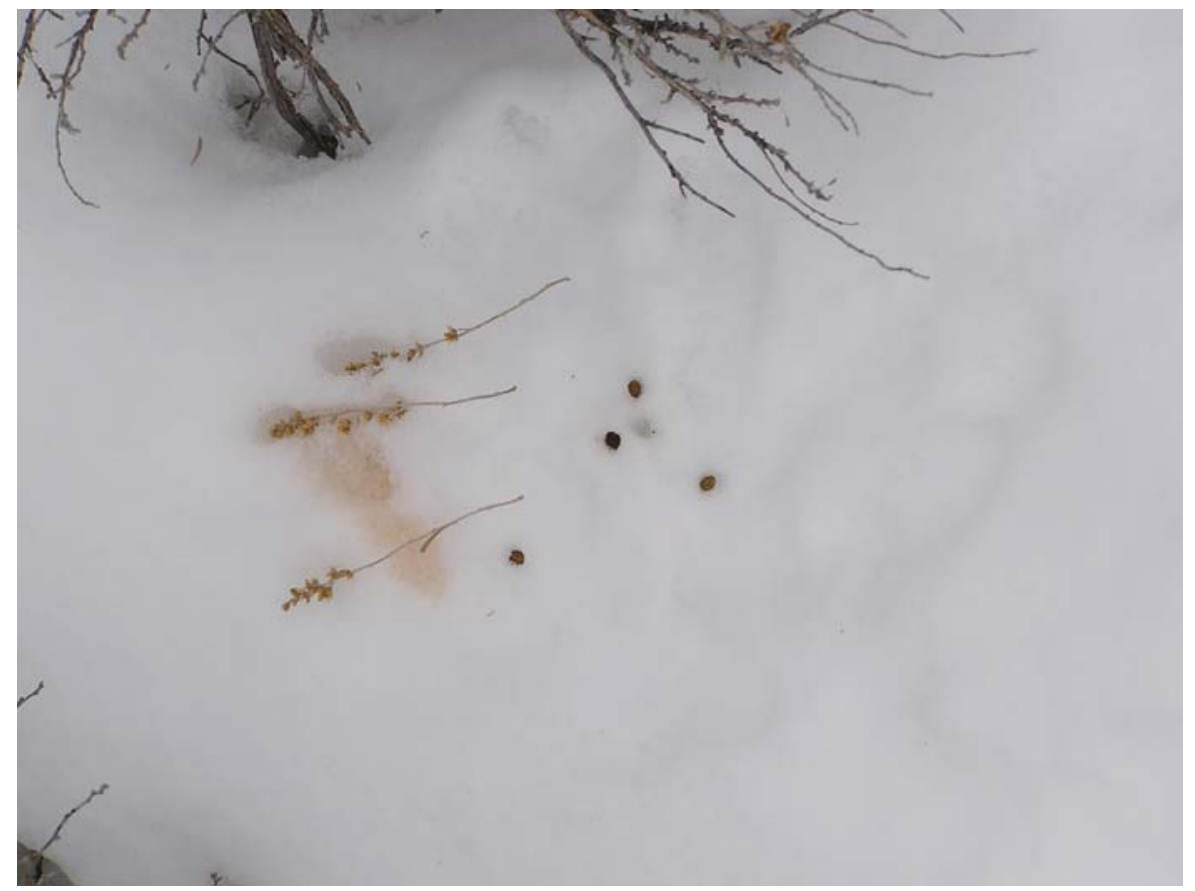

Photo 6. Pygmy rabbit tracks, urine stain, and sagebrush floret clippings in snow. 


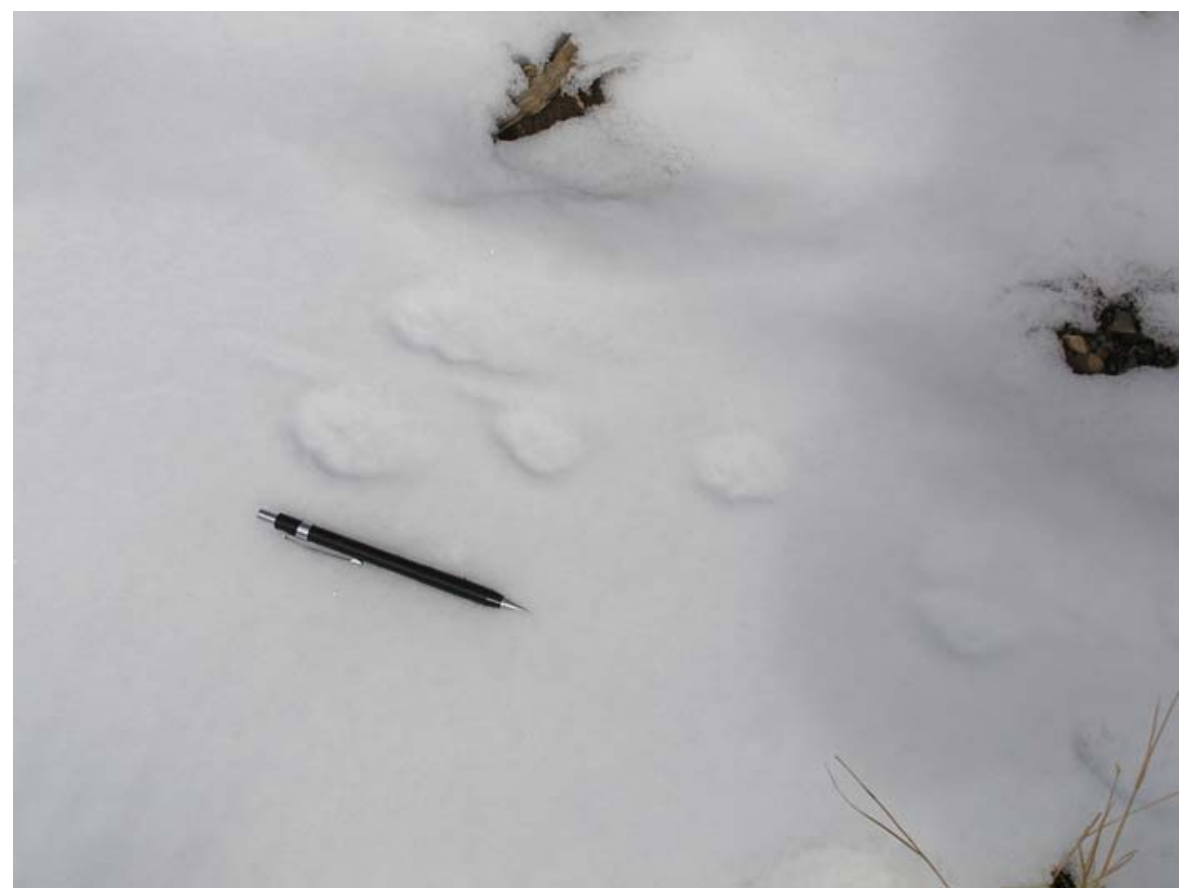

Photo 7. Pygmy rabbit tracks in snow.

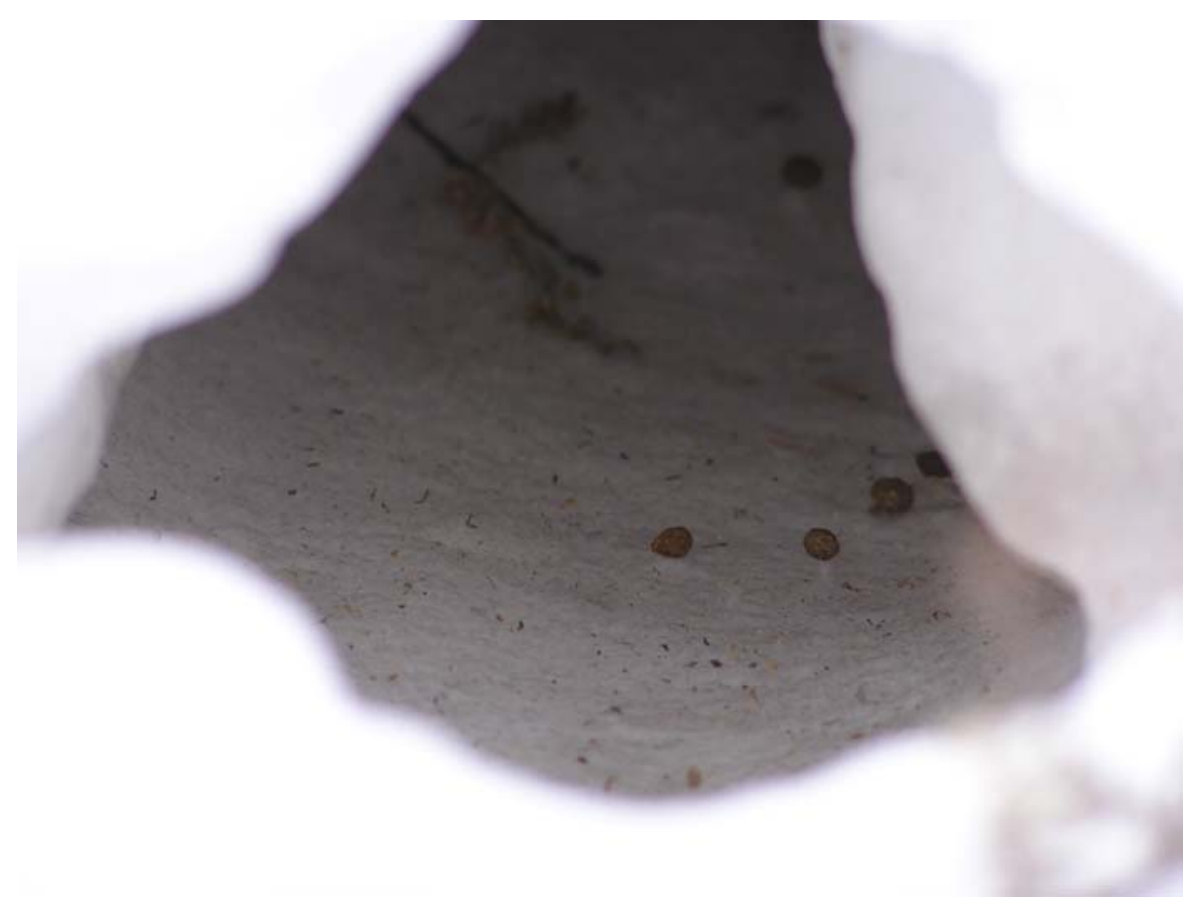

Photo 8. Pygmy rabbit burrow entrance in snow.

Note pellets and sagebrush clippings at base. 


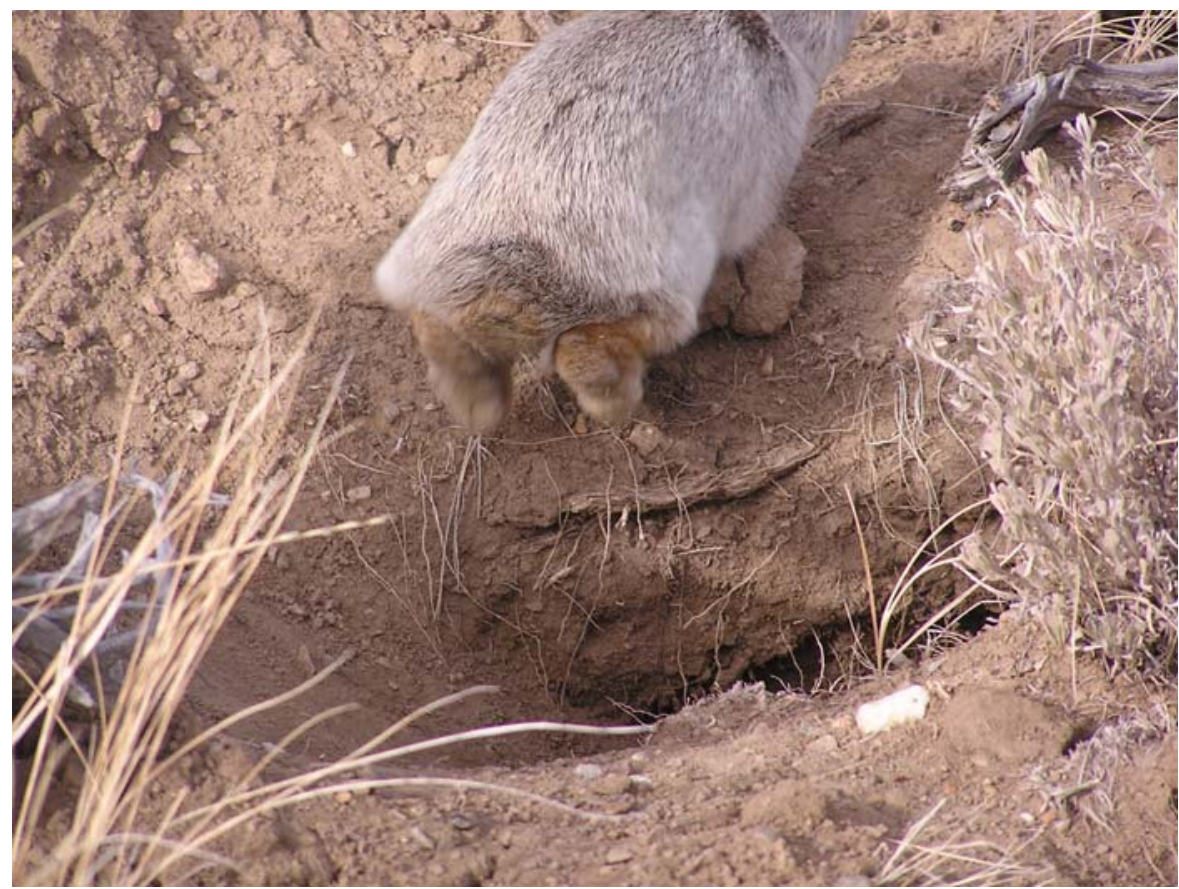

Photo 9. Absence of white tail clearly distinguishes pygmy rabbits from cottontail rabbits. 



\section{Appendix 3: Model Output}

Map 1. Conservative GAP30 model

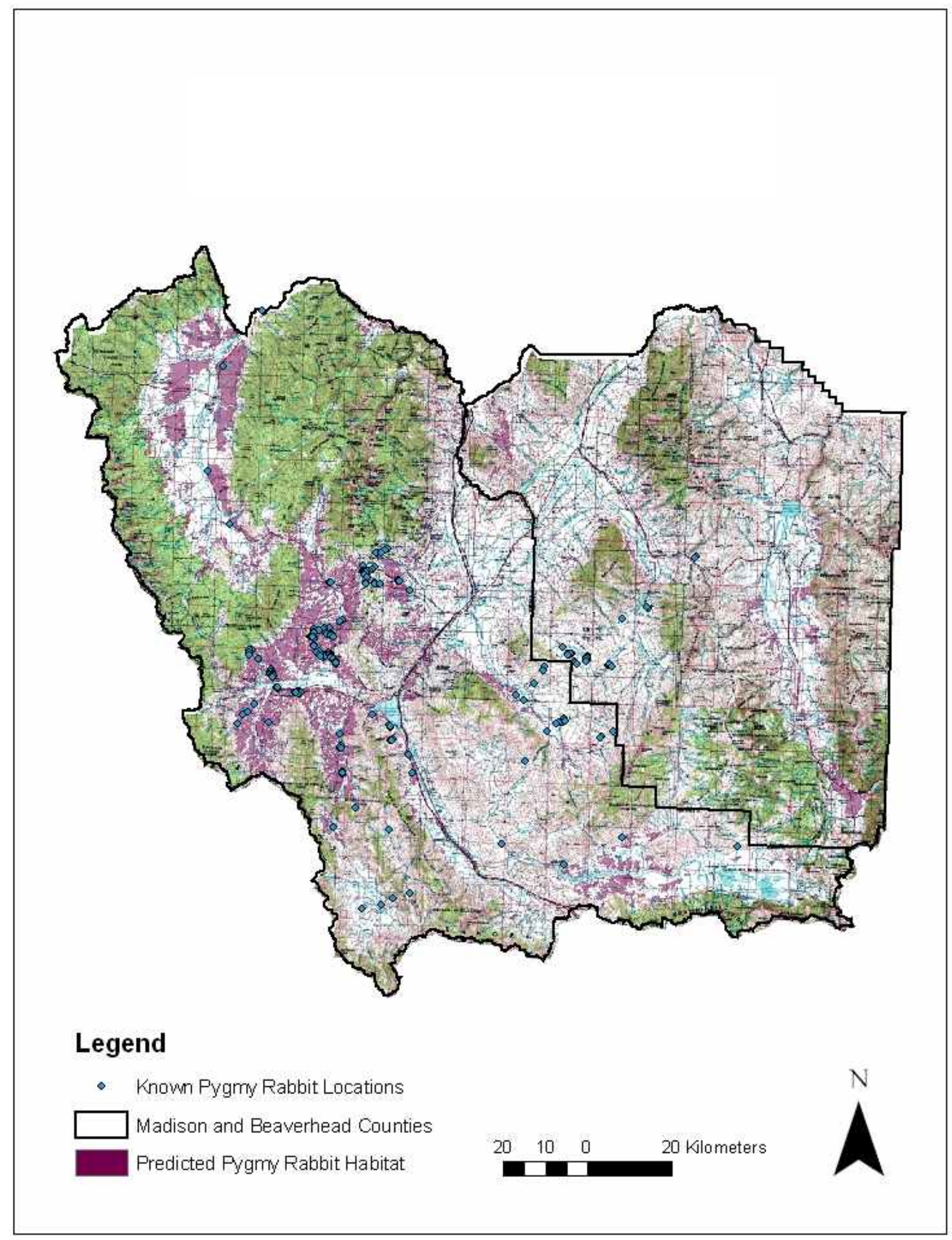




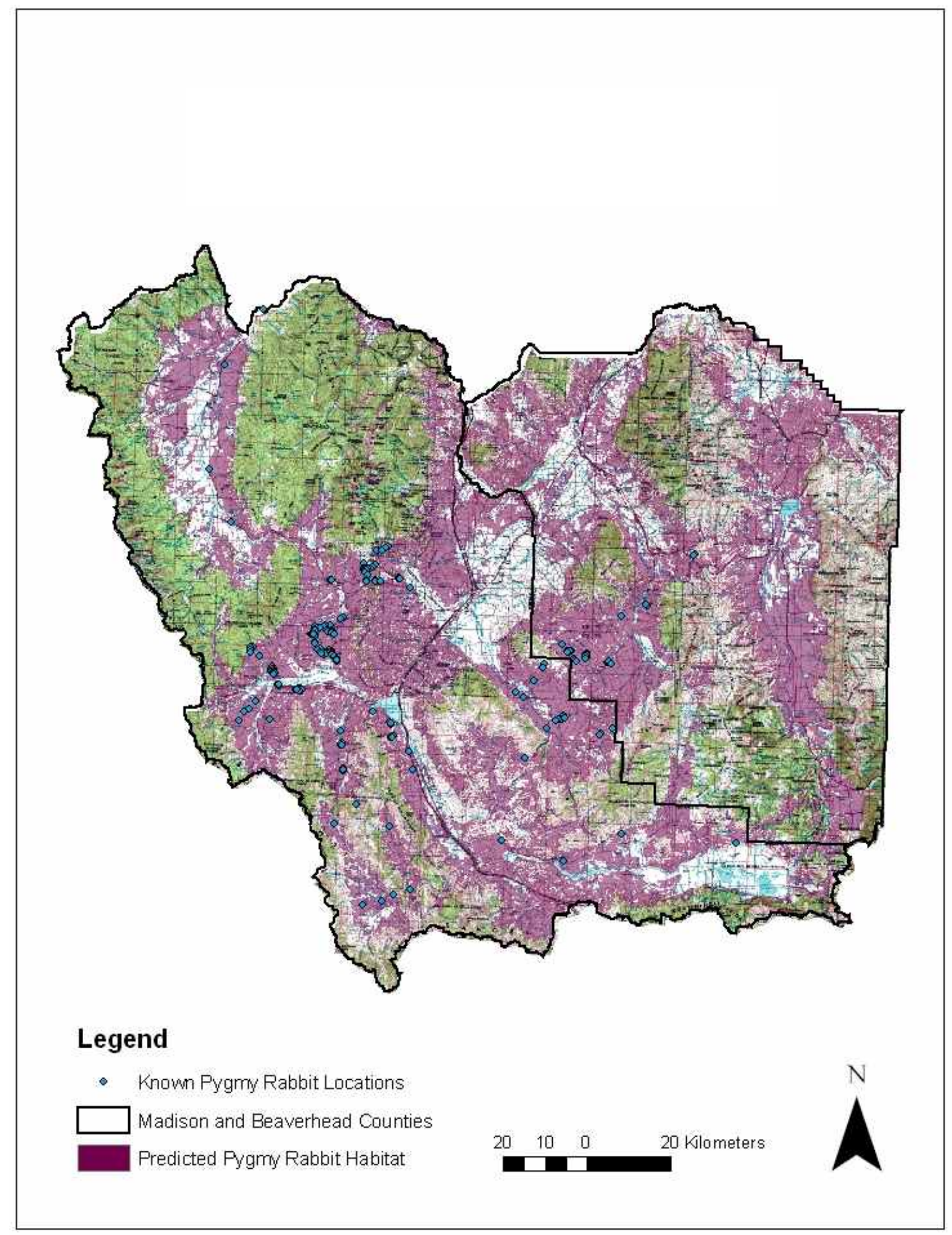




\section{Map 3. Conservative SILC3 Model}

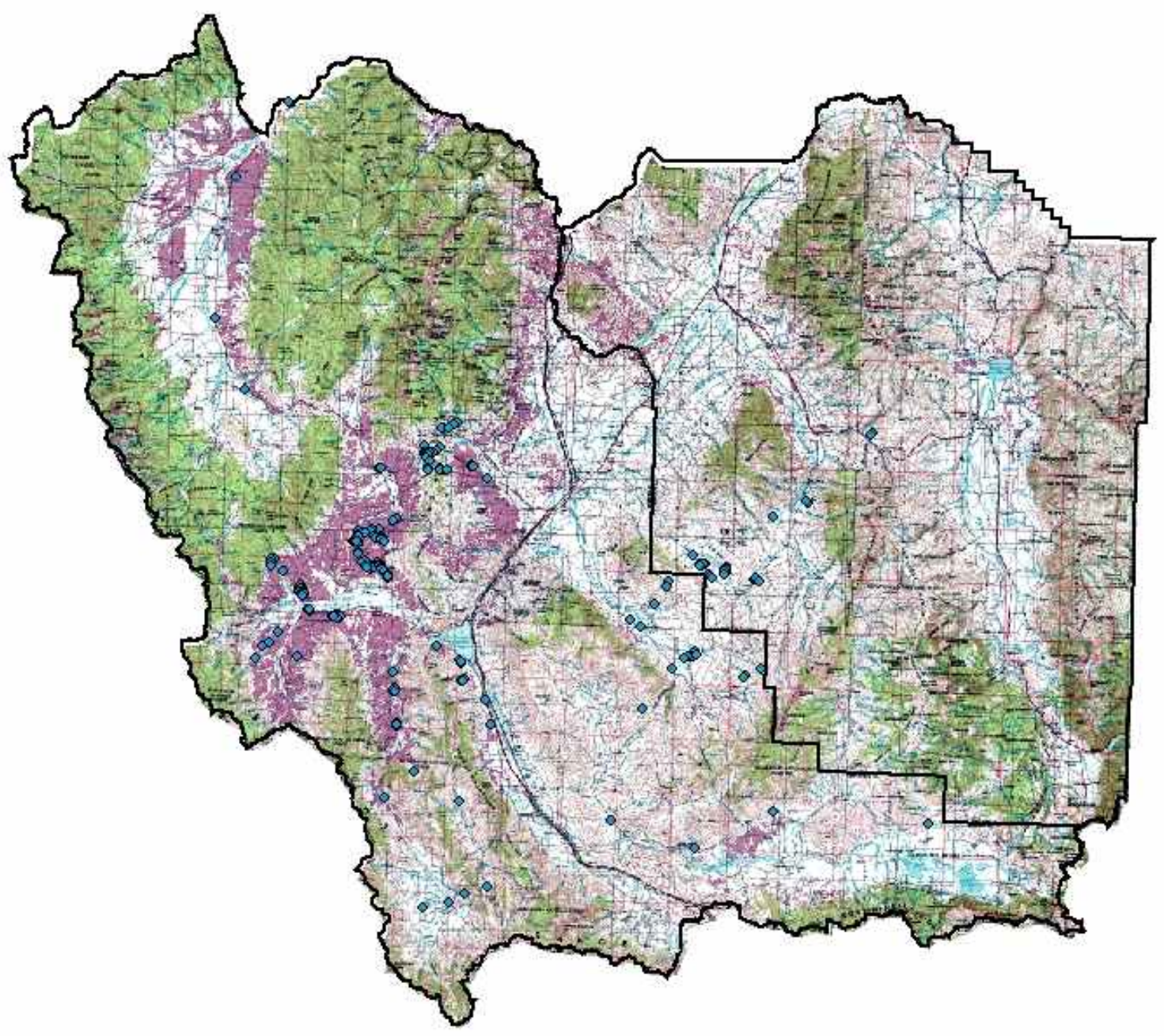

\section{Legend}

- Known Pygmy Rabbit Locations

$\square$ Madison and Beaverhead Counties

Predicted Pygmy Rabbit Habitat
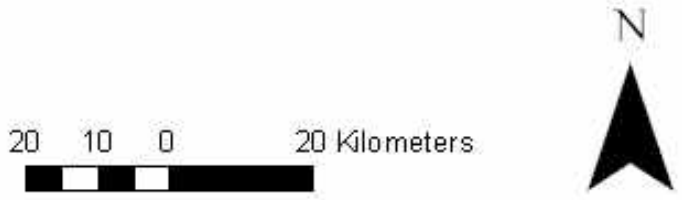


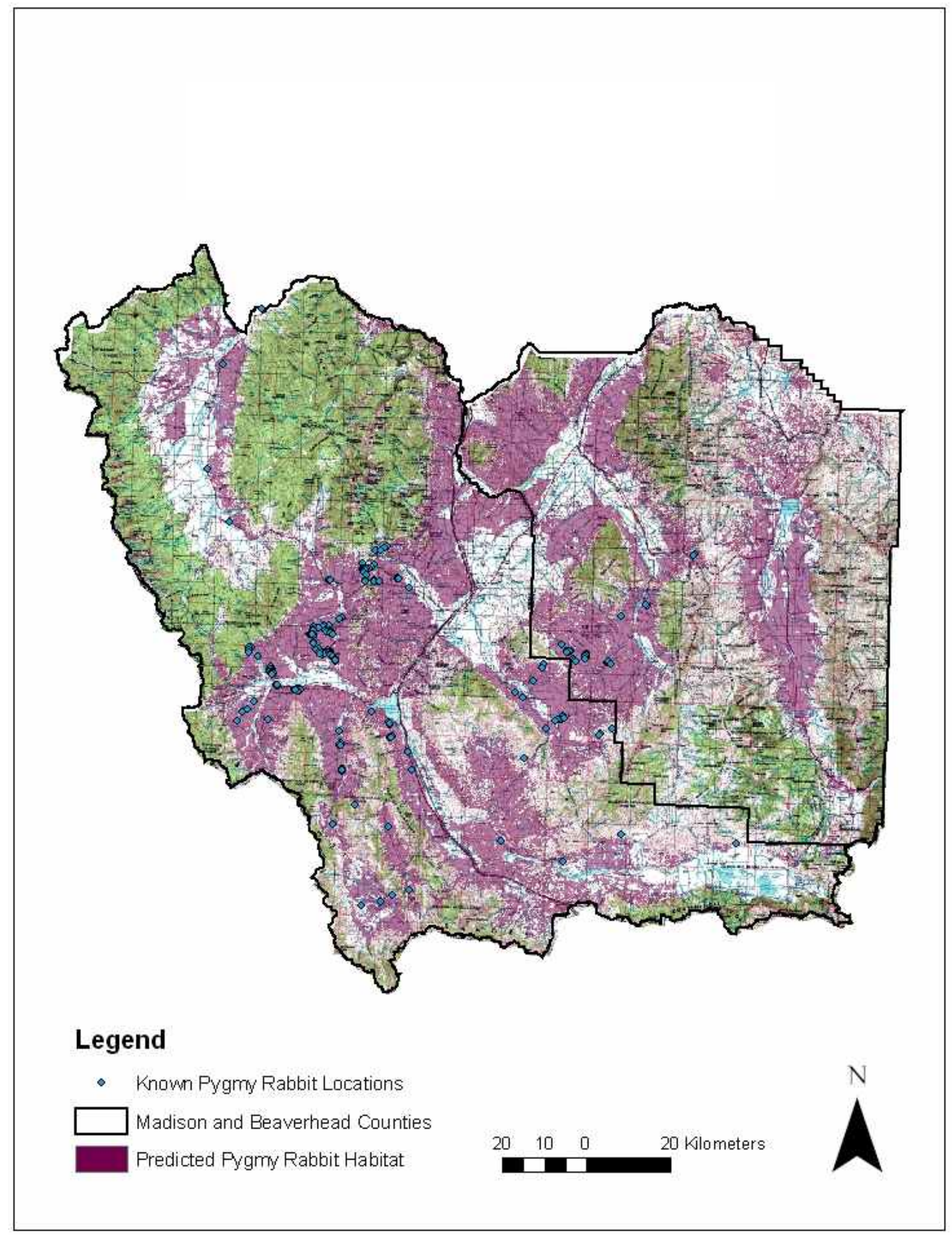


Map 5. Liberal model with SILC3 moderate and high sagebrush cover types

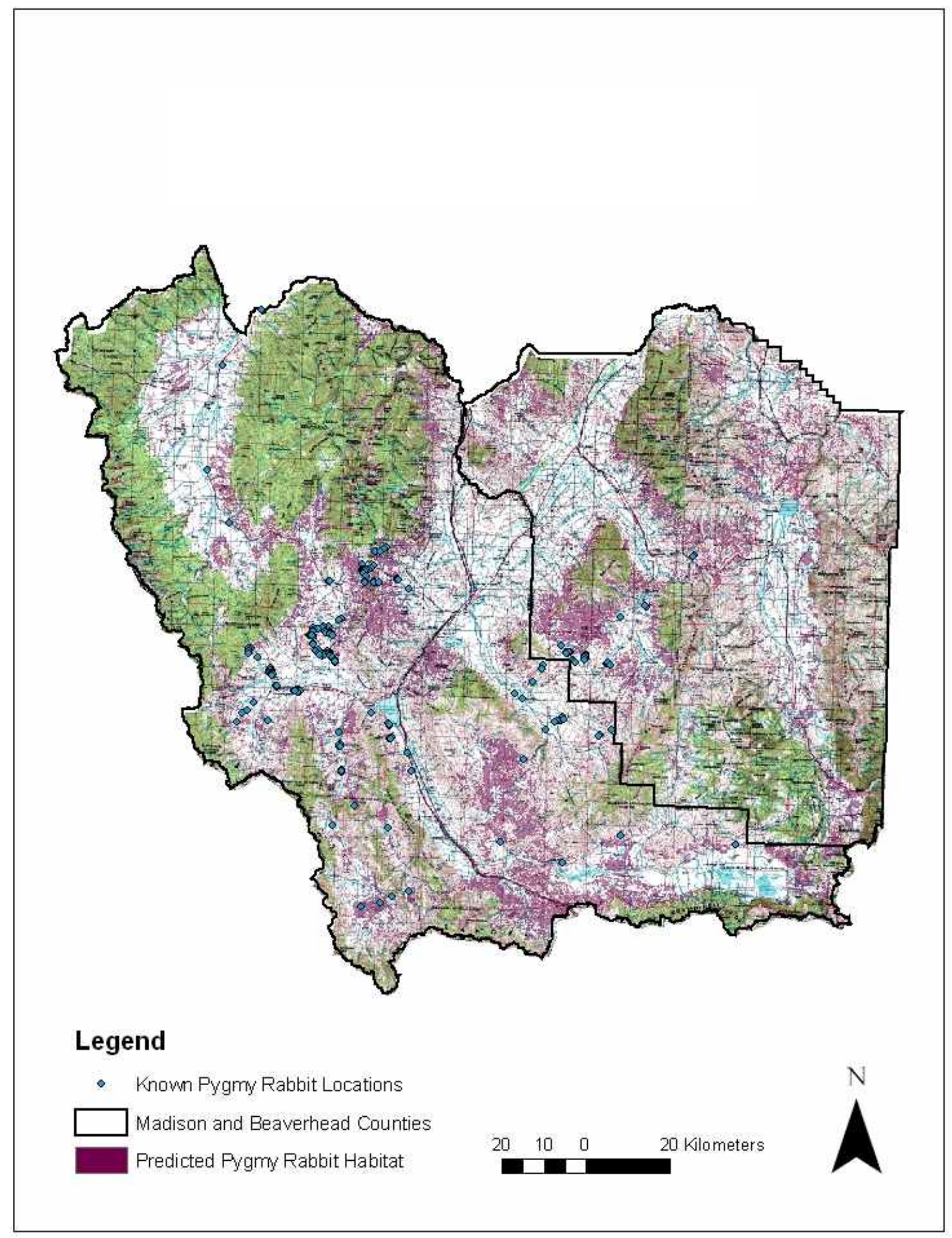

